\title{
Employee Ownership and Firm Disclosure
}

\author{
Francesco Bova \\ Rotman School of Management \\ University of Toronto \\ Francesco.Bova@rotman.utoronto.ca \\ Yiwei Dou \\ Rotman School of Management \\ University of Toronto \\ Yiwei.Dou07@rotman.utoronto.ca \\ Ole-Kristian Hope \\ Rotman School of Management \\ University of Toronto \\ okhope@rotman.utoronto.ca
}

January 22, 2011

\begin{abstract}
Evidence suggests that managers have an incentive to keep information opaque with the market when negotiating with non-manager employees who can extract above-market rents from the firm. We provide empirical evidence which suggests that employee ownership mitigates this incentive. Using a matched sample design and employing a rich set of proxies for voluntary disclosure, we find that firms whose non-manager employees have strong bargaining power provide less voluntary disclosure whereas firms whose non-manager employees have employee stock ownership plans provide greater voluntary disclosure. Furthermore, the effect of employee ownership in generating better disclosure is particularly strong, the greater employees' negotiation leverage. Our results suggest a novel capital market benefit to utilizing employee ownership. Specifically, employee ownership appears to benefit the firm by not only aligning goals between the firm and its non-manager employees, but by also increasing disclosure from the firm to all of its stakeholders by mitigating the firm's need to keep information opaque.

Keywords: Employee ownership, union bargaining power, voluntary disclosure, research design

We thank workshop participants at the Rotman School of Management and the Labor and Employment Relations Association $63^{\text {rd }}$ Annual Meeting and Joseph Blasi for helpful comments. We are also grateful for funding from the Rotman School of Management, the Rutgers Fellowship for Research in Employee Ownership (Bova), and the Deloitte Professorship (Hope).
\end{abstract}




\section{Employee Ownership and Firm Disclosure}

\section{Introduction}

The pros and cons of employee ownership have inspired much debate in recent years. On the one hand, advocates of employee ownership cite evidence which suggests that employee ownership leads to increasing employee-manager goal alignment and productivity gains that are ultimately reflected in higher shareholder returns (Jones and Kato 1995; Kruse et al. 2009). On the other hand, contrasting empirical evidence suggests that giving non-manager employees too much ownership in the company can erode shareholder value (La Porta et al. 1997). ${ }^{1}$ Our study adds to this debate by assessing the role of employee ownership in shaping management's incentive to disclose information to the market. Our results illustrate a positive link between employee ownership and voluntary disclosure and suggest that employee ownership may play a role in improving a firm's corporate governance, by improving its transparency with investors and other stakeholders.

In drawing a link between employee ownership and voluntary disclosure, we build on economic theory which suggests that firms benefit from the voluntary revelation of information to the capital markets. Specifically, in the absence of costs (e.g., Jovanovic 1982; Verrecchia 2001) or uncertainty about the existence of information (e.g., Dye 1985; Jung and Kwon 1988), theory suggests that firms should follow a policy of fully eliminating information asymmetry with the market. However, despite the conjectured benefits to full disclosure, we observe great variation in disclosure quality across firms. This variation implies that there may be costs to full disclosure. One type of cost that may lead to variation in disclosure arises from firms' incentives

\footnotetext{
${ }^{1}$ For example, in 1995, United Airlines awarded employees 55\% of the firm's equity in exchange for concessions on salaries and benefits. While the plan at the time was applauded by the U.S. Federal government as an innovative way to heal the fractious nature of the union-management relationship, others remained skeptical of allowing a stakeholder that already contracted with the firm enough power to essentially control the firm's decision making.
} 
to keep information asymmetric when stakeholders can use firm disclosures to extract rents from the firm. The classic example of this type of tension is that of a firm withholding information in order to avoid revealing strategic advantages to its competitors (Verrecchia 2001). Our study focuses both on the firm's non-manager employees as a group of stakeholders that have the potential to extract above-market rents from the firm and on employee ownership as a tool to mitigate this potential to extract rents.

To start, if the firm's non-manager employees have the ability to extract above-market rents from the firm (i.e., obtain wage premia above the competitive market wage), then managers may have a desire to reduce disclosure in order to prevent those rents from being extracted. There is evidence to support this conjecture. For example, Hilary (2006) cites evidence which suggests that revealing information in a unionized environment weakens management's position during the collective bargaining process. Hilary (2006) supports this point by illustrating that firms with strong organized labor also have larger information asymmetries.

We posit that employee ownership alleviates this incentive to keep information asymmetric with non-manager employees and, more broadly, the market in general. Our reasoning is in part motivated by analytical and empirical findings in Cramton et al. (2008) which suggest that employee stock ownership leads to: a weaker bargaining position for nonmanager employees; the firm becoming more amenable to initial wage demands; and a smaller number of labor disputes involving strikes. We argue that employee ownership, through its ability to align employee-shareholder objectives and reduce the employee base's bargaining power, should both decrease the negative consequences to disclosing information to employees and mitigate the incentive for management to keep information asymmetric with the market. 
We test these predictions using a very rich set of proxies to capture different dimensions of discretionary disclosure. Specifically, we employ nine individual disclosure proxies: five management guidance-based measures, two conference call metrics, and two annual report readability scores. In addition, we report results using an aggregate measure for voluntary disclosure.

Our primary research design is based on comparing all U.S. publicly-traded firms with employee stock ownership plans (ESOPs) to a sample of non-ESOP firms, matched on parameters that proxy for a firm's incentive to adopt an ESOP. In addition, our multivariate analyses include an extensive set of control variables motivated by prior research. In sensitivity analyses we provide supporting evidence using several alternative attribute-based matching procedures (i.e., matching on different firm characteristics, using one-to-many instead of one-toone matching, and including matched pair fixed effects), propensity score matching, a Heckman self-selection test, changes tests, non-matching-based tests, and other robustness analyses.

Our evidence is consistent with our conjectures. Utilizing data from 1999 - 2007, we find that, relative to a non-ESOP control group, our ESOP sample firms are more likely to: issue management forecasts, produce more forecasts on average, issue more good news and bad news forecasts, have higher quality management guidance, initiate and provide more conference calls, have more readable annual reports (measured as both the Fog index and the excessive length of the annual report), and have higher aggregate disclosure scores.

In a second set of tests, we incorporate a proxy for employees' negotiation leverage (i.e., the unionization rate of a firm's industry). Across all of the aforementioned disclosure proxies, we find that firms that employ workers with greater negotiation leverage disclose less. Finally and importantly, we predict and find that the relation between employee ownership and higher 
quality disclosure is generally larger, the stronger the negotiation leverage of the employee base (i.e., the interaction term between employee ownership and unionization rates is significantly positive). This final result strengthens the case for a causal link between employee ownership and discretionary disclosure because employee ownership should have a bigger impact on improving a firm's disclosures the greater the employees' ability to extract rents from the firm, and hence, the larger the firm's incentive to withhold information in the first place. Further strengthening the causal link is the fact that we find the observed effect to be stronger in the postReg FD period when managers should have a greater incentive to utilize an opaque disclosure policy in order to maintain their informational advantage over employees.

In additional tests we find that, as unionization rates increase, ESOP firms are more likely to have smaller information asymmetries (i.e., smaller bid-ask-spreads and PIN measures). These results provide further evidence that ESOPs mitigate the incentive to keep information asymmetric, the greater employees' negotiation power.

The collective evidence points to employee ownership as an interesting new determinant for several facets of voluntary disclosure. More broadly, the study identifies a novel capital market benefit to firms' utilizing employee ownership. Specifically, a firm's use of an employee stock ownership plan appears to benefit the firm by not only aligning goals between the firm and its non-manager employees, but by also increasing disclosure from the firm to all of its stakeholders by mitigating the firm's need to keep information opaque for "proprietary cost" reasons. This benefit, while potentially unintended, illustrates that employee ownership for nonmanager employees may improve a firm's corporate governance, by allowing it to become more transparent. 
The next section provides background discussion and develops our hypotheses. Section 3 explains how we measure voluntary disclosure and employee ownership. Section 4 details our research design choices. Section 5 describes the sample and provides correlation results. We present multivariate test results (including results of additional analyses and robustness tests) in Section 6, and Section 7 concludes. Finally, the Appendix provides detailed definitions of all variables used in the study.

\section{Hypotheses Development}

The role of disclosure in the capital markets remains an important topic in accounting research (Beyer et al. 2010). In particular, accounting theorists have long questioned why we empirically observe variation in the type and quality of disclosure across firms, given both the capital market benefits to being transparent and the legal costs to not disclosing information on a timely basis. One possible explanation is that firms have an incentive to disclose less when other market participants can use the information to extract rents from the firm (Verrecchia 2001; Darrough 1993). The classic example is that of a competitor using a firm's disclosures to glean a competitive advantage from its rival (i.e., proprietary costs of disclosure). However, other examples abound. For instance, prior studies find evidence that firms that contract with powerful suppliers or buyers will often adopt different disclosure practices in an attempt to prevent rent extraction from those suppliers or buyers. ${ }^{2}$

We focus on the firm's non-manager employees as a group of stakeholders that have the potential to extract above-market rents from the firm and on employee ownership as a tool to mitigate this potential to extract rents. The literature provides evidence that managers have an

\footnotetext{
${ }^{2}$ For evidence on how accounting and disclosure choices are made to obtain favorable terms with customers and suppliers, see Bowen et al. (1995), Raman and Shahran (2008), and Dou et al. (2010).
} 
incentive to keep information asymmetric with the market if non-manager employees can extract above-market rents from the firm - for example, in cases where the employee base is highly unionized (e.g., Bova 2010; Hilary 2006; Scott 1994). As suggested above, the benefit to the strategy of disclosing less is that reduced transparency should weaken the employees' bargaining position. However, an opaque disclosure policy keeps information asymmetric with not only employees, but also investors and other stakeholders. As a result, there are costs to reduced disclosure. These costs might include a higher cost of capital and a higher bid-ask spread for the firm's stock (Botosan 1997; Healy et al. 1999; Lang and Lundholm 1996). ${ }^{3}$ Clearly, in equilibrium, firms would only restrict disclosing information if the benefits to doing so outweighed these costs.

We build on this work by assessing employee ownership as a tool to mitigate the tension described above. Cramton et al. (2008) model the impact of employee ownership in a unionized setting. Their model suggests that employee stock ownership leads to: a weaker bargaining position for the union, the firm becoming more amenable to initial wage demands, and a smaller number of labor disputes involving strikes. The decrease in bargaining power arises as employee compensation becomes more closely linked to the stock returns of the firm, leading to any costly negotiation frictions (e.g., extended negotiations or strikes) impacting employee compensation to a greater extent.

Hilary (2006) provides a useful summary of the large literature supporting the hypothesis that management tries to hide information in general from employees (and in particular from unions). According to this review, it seems well accepted among practitioners that reducing the information asymmetry with labor would be damaging to management, and ultimately the firm's

\footnotetext{
${ }^{3}$ There may be other, non-capital market costs to an opaque disclosure policy as well. For example, highly qualified potential employees could be more willing to accept a job offer from a firm that has an established track record for being transparent.
} 
shareholders. For example, according to Reynolds et al. (1998), an important feature of labor negotiations is an effort to conceal or even misrepresent one's true position. Supporting this view, Leap (1991) argues that unions generally do not have access to an employer's production, financial, and personnel information. Supporting evidence can also be found in empirical, clinical, and experimental evidence. For example, Scott (1994) provides evidence that firms that face a higher likelihood of strikes or that operate in industries with high average salaries reduce their pension-related disclosures. Further related research evidence is reported in Frost (2000), Croson (1996), Kochan and Katz (1988), and Cukierman and Meltzer (1986).

Taken together, we argue that as employee ownership for non-manager employees aligns employee-shareholder objectives and decreases employee negotiation leverage, it should also decrease any negative consequences to transparency. In other words, employee ownership should mute the benefits to reduced public disclosure by mitigating non-manager employees' ability to extract above-market rents from the firm. Conversely, employee ownership should have no effect on the costs to having an opaque disclosure policy (e.g., a higher cost of capital). As the benefits to limited disclosure should decrease with employee ownership while the costs remain unaffected, firms with employee stock ownership plans should be less likely to withhold information than firms without such plans. ${ }^{4}$

Thus our first hypothesis is as follows:

\section{H1: There is a positive relation between employee ownership and the level of a firm's voluntary disclosure.}

\footnotetext{
${ }^{4}$ We expect this outcome provided the average firm in our sample contracts with employees that have a strictly positive level of negotiation leverage.
} 
While we posit that a positive relation exists between employee ownership and voluntary disclosure, we also predict that firms have an incentive to disclose less information when facing an employee base with negotiation leverage. The link between employees' negotiation leverage and their ability to extract rents from the firm takes its foundation from economic theory. For example, McDonald and Solow (1981) illustrate that if non-manager employees have no negotiation leverage, then employees should be paid the competitive market reservation wage. At this extreme, the firm should in turn have no incentive to reduce disclosure, as its employees receive the competitive market wage regardless of the firm's profitability. At the other extreme, where employees have all the negotiation leverage, employees should extract all of the firm's profits as compensation. In this second setting, the firm should have a greater incentive to keep information asymmetric in order to weaken employee bargaining positions and, ultimately, retain more profits for its shareholders.

We proxy for employee negotiation leverage using the percentage of unionized employees in the firm's industry. The literature observes that unionized employees have more negotiating power than their non-unionized counterparts, due in large part to the union's ability to negotiate on behalf of an entire group of workers. Additionally, the prior literature has used the percentage of unionized employees as a proxy for employee negotiation leverage. For example, Bova (2010) and Hilary (2006) use union density at the firm- and industry-level, respectively, as proxies for employees' negotiation strength. Both articles find that the firm's incentive to keep information asymmetric with the market is increasing in these proxies - a result consistent with management's incentive to disclose less information in the face of an abovemarket rent-extracting employee base. This leads to the following hypothesis: 
H2: There is a negative relation between the union density of a firm's industry and a firm's voluntary disclosure.

The Cramton et al. (2008) model suggests that employee stock ownership leads to: a weaker bargaining position for the union, the firm becoming more amenable to initial wage demands, and a smaller number of labor disputes involving strikes. The decrease in bargaining power arises as employee compensation becomes more closely linked to the stock returns of the firm, leading to any costly negotiation frictions (e.g., extended negotiations or strikes) impacting employee compensation to a greater extent.

Following the arguments in Cramton et al. (2008) and the inferences from $\mathrm{H} 1$ and $\mathrm{H} 2$, if a firm has an incentive to disclose less information the greater its employees' negotiation leverage, and if employee ownership mitigates employees' negotiation leverage, then we should observe employee ownership having a more significant effect on improving disclosure, the greater the negotiation leverage of the employee base. This leads to our final hypothesis:

\section{H3: The positive relation between employee ownership and the level of a firm's voluntary disclosure is larger for firms in industries with higher union density.}

We note that the hypotheses suggested above are separate and distinct from those found in the literature which conjectures that equity-based compensation should reduce a manager's agency issues, and in turn improve disclosure. A good example of a paper from this literature is Nagar et al. (2003). Focusing on top managers' stock-based incentives, Nagar et al. find that stock-based incentives can reduce agency problems between managers and shareholders, and 
thus increase the incentives for managers to disclose information. The difference between the hypotheses conjectured in Nagar et al. and the hypotheses posited in our paper are as follows. First, we focus on employee ownership for non-manager employees as opposed to employee ownership for managers. ${ }^{5}$ Thus, the market participant that receives equity-based compensation in our model (i.e., the non-manager employee) differs from the one that makes the disclosure decision (i.e., the manager). In contrast, the market participant that receives equity-based compensation in Nagar et al. (i.e., the manager) is the same one that makes the disclosure decision. Second, Nagar et al. conjecture that the manager will disclose more information due to equity-based compensation mitigating the manager's agency problem. In our paper, the manager discloses more information due to equity-based compensation reducing the negotiation leverage of non-manager employees. To sum: Nagar et al. explore variation in disclosure through stock ownership's ability to reduce a manger's incentive to shirk, while our paper explores disclosure differences through stock ownership's ability to mitigate non-manager employee bargaining power.

Finally, by assessing the interaction between a firm's union density and its employee ownership in $\mathrm{H} 3$, we are able to more accurately distinguish between the economic phenomenon documented in Nagar et al. and the economic phenomenon posited in our paper. We can make this distinction because managers are typically non-unionized. Thus, if our results are simply capturing equity ownership's ability to mitigate managers' agency costs (as conjectured in Nagar et al.), we should find evidence consistent with $\mathrm{H} 1$ but not $\mathrm{H} 3$, as disclosure should then vary independently of non-manager employee negotiating power. Conversely, evidence consistent with H3 would provide support for the hypotheses posited in this paper.

\footnotetext{
${ }^{5}$ Our construct for employee ownership proxies for the ownership of non-manager employees as opposed to the ownership of managers. We discuss the construct validity of our employee ownership proxy in Section 3.
} 


\section{Measurement of Dependent and Test Variables}

\subsection{Voluntary Disclosure Proxies}

Compared with extant research we use an unusually rich set of proxies to capture different aspects of firms' disclosure practices: (1) management guidance, (2) conference calls, and (3) annual report readability. Given the importance of management guidance in recent disclosure research (see below), we employ five guidance-based proxies. We further consider two dimensions of each of conference calls and readability. Finally, we form an aggregate disclosure proxy by averaging the nine disclosure metrics. We view this contribution as important for three reasons. First, the construct we are interested in is discretionary disclosure, which clearly is multi-dimensional. Thus, a single proxy is unlikely to cover all facets of financial transparency. ${ }^{6}$ Second, the use of multiple proxies increases the generalizability of our results. Third, using alternative measures mitigates the possibility that results using one particular disclosure proxy capture some factor other than disclosure, and that this other factor is driving our results.

\section{Management Guidance}

Perhaps the most widely used disclosure proxy in recent accounting research is management guidance (or management earnings forecasts). ${ }^{7}$ Management guidance is typically issued by managers through press releases. In addition to a forecast, management guidance typically includes additional qualitative disclosures. For example, Baginski, Hassell, and Kimbrough (2004) find that about three quarters of management forecasts include a discussion

\footnotetext{
${ }^{6}$ For example, Rogers and Van Buskirk $(2009,142)$ argue that “... conference calls and [management] forecasts are the best direct measures of a firm's disclosure policy, but we recognize that they are incomplete."

${ }^{7}$ See Hirst et al. (2008) for a review of the large literature on management earnings forecasts as a disclosure proxy.
} 
and explanation for the forecasted performance (see also Hutton et al. 2003 and De Franco et al. 2010). Baginski et al. (2004) show that management forecasts are accompanied by disclosures that link the forecasted performance with both internal management actions (e.g., new products, prices, strategies, and capital investments) and external issues (e.g., input prices, legal actions, and exchange rates). They argue that these attributions potentially aid investors by confirming known relations between attributions and performance or identifying additional causes of performance.

Additionally, research shows that firms issue guidance to align the market's expectations with their own earnings assessments (King et al. 1990). In other words, managers use guidance to mitigate information asymmetry between investors and managers or to preempt litigation concerns (Coller and Yohn 1997; Marquardt and Wiedman 1998). Research also indicates that managers issue guidance as they care about their reputations for transparent and accurate reporting (Graham et al. 2005). In sum, management guidance has been shown to be an effective way of improving the firm's information environment and thus its overall financial transparency.

In our empirical tests, we first include an indicator variable $(M F)$ that equals one if the firm issues guidance that particular year, otherwise zero. Second, as many firms provide more than one earnings forecast per year, we measure the number of guidance events per year and use the log of one plus the number of forecasts issued $(N M F)$. Our third and fourth measures are based on Chen et al. (2008) and reflect whether investors consider the information in the press release to be good or bad news. In particular, following Chen et al. (2008) we measure cumulative abnormal returns centered on the forecast date, and define positive (negative) abnormal returns as good (bad) news. The third and fourth measures are then the log of one plus the number of good news $(N G M F)$ and bad news $(N B M F)$ forecasts during the year, respectively. 
Finally, our most comprehensive metric is a measure of the quality of management guidance based on the Francis et al. (2008) management forecast score (MFS). This score measures how "specific" the forecasts are. It is equal to 1 for qualitative guidance (e.g., earnings outlook improved), 2 for open-ended guidance (e.g., earnings should exceed the prior period), 3 for range guidance (e.g., earnings fall between $\mathrm{x}$ and $\mathrm{y}$ ), and 4 for point guidance (i.e., an actual earnings estimate). Following Francis et al. (2008), we then sum the scores for each firm by year. We use both quarterly and annual management earnings guidance to construct our guidance measures.

\section{Conference Calls}

We use conference calls as our second set of disclosure metrics. A number of studies use conference calls to study firms' voluntary disclosure decisions (e.g., Frankel et al. 1999; Bowen et al. 2002; Bushee et al. 2003, 2004; Rogers and Van Buskirk 2009). Our measurement of conference calls is straightforward and consistent with prior research. Specifically, we collect the number of conference calls held by the firm for each year from BestCalls.com. We measure both the existence of a conference call $(C C)$ in a given year and (the log of one plus) the number of conference calls (NCONFC) held that year.

\section{Annual Report Readability}

Our third group of disclosure proxies is quite different from the first two. Here we focus on financial report readability which captures characteristics (rather than the content) of disclosure. Regulators argue that it is imperative that company financial reports be more readable and easier to comprehend. For example, the SEC has guidelines in place that encourage firms to 
use plain English in their financial disclosures (SEC 1998). The idea is that reports that are difficult to read increase information-processing costs for investors and hence constitute lower quality disclosures. $^{8}$

Following Li (2008), we use two statistics to measure annual report readability. First, we compute the Fog index, which has been employed in recent studies (e.g., Li 2008; Biddle et al. 2009; Lawrence 2010). This index, which is based on computational linguistics, is a direct measure of the readability of text. Specifically, it captures reading complexity as a function of syllables per word and words per sentence ( $\mathrm{Li} 2008$, 225). Li (2008) shows that firms with a large Fog index are associated with a lower earnings persistence and lower future profitability.

The second measure, the length of the annual report, may appear less intuitive at first sight. However, the underlying idea is that, ceteris paribus, longer documents are more difficult to read and process for users of financial statements. ${ }^{9}$ We measure length as the log of the number of words in the annual report. An obvious alternative explanation for a lengthy document is that the firm is more complex. Thus, our multivariate tests control for numerous factors related to firm complexity. In other words, this measure of annual report length can be considered the document length beyond what is explained by normal factors (or excessive length). Finally, we multiply both the Fog index and length by -1 so that the ensuing scores (FOGINV and LENGTHINV) are increasing in disclosure quality (and thus consistent with our other disclosure proxies).

\footnotetext{
${ }^{8}$ The Director of the SEC's Office of Investor Education and Assistance states that "Probably the most familiar theme is plain language. The swamp of legalese found in many annual reports and mutual fund prospectuses can frustrate even the most experienced investor. Not surprisingly, investors consistently have been telling us that disclosures should contain language that the average investor, not the average lawyer, can read and understand" (Schock 2007).

${ }^{9}$ For example, the SEC strongly suggests that firms avoid lengthy documents (SEC 1998).
} 
Lastly, to mitigate measurement error in the individual disclosure components, and to provide evidence based on an overall disclosure metric, we aggregate all nine proxies into one aggregate score. Specifically, following Biddle et al. (2009) we first normalize all proxies and then take the average of the nine measures as our summary statistic for financial disclosure (DSCORE).

\subsection{Measurement of Employee Ownership and Labor Negotiation Leverage}

\section{Employee Ownership}

For our empirical tests, we restrict our analysis to all U.S. firms with employee stock ownership plans (ESOPs) from 1999 - 2007 (and a matched sample of firms as described below). We measure employee ownership with a binary variable that indicates whether a firm has at least one ESOP in a given year. To generate the ESOP data we search all Form 5500 filings from 1999 - 2007. ${ }^{10}$ If a Form 5500 filing indicates an ESOP exists for a particular business entity, we take the business entity's EIN number from the filing and match it to its firm's EIN number in Compustat. ${ }^{11}$ We include all publicly-traded firms with at least one ESOP in a given year in the $E S O P$ sample group for that year.

We restrict our attention to firms with ESOPs as opposed to other investment vehicles which may include employer stock (e.g., 401(k) plans) for the following reasons. First, and most importantly, ESOPs are economically significant. According to the National Center for

\footnotetext{
${ }^{10}$ We access Form 5500 filing data from the King of Pension Funds database from Judy Diamond Associates Inc. These data are available from the King of Pension Funds database from 1999 onward. We include all firms with ESOPs, leveraged ESOPs, and combined ESOP/401Ks (often known as KSOPs) from 1999 - 2007 in our initial sample.

${ }^{11}$ An Employer Identification Number (EIN) is also known as a Federal Tax Identification Number, and is used to identify a business entity. As many publicly-traded firms have multiple business segments, multiple EINs can belong to the same firm.
} 
Employee Ownership, in 2007, nearly 14 million employees participated in 9,650 ESOPs, with combined assets over $\$ 925$ billion at public and private firms. The corresponding numbers for 401(k) plans are 7 million participants with $\$ 275$ billion in assets (Kim and Ouimet 2009). ${ }^{12}$

Second, whereas an ESOP has the majority of its assets invested in the employer's stock, a 401(k) plan typically contains significantly less employer stock as a percentage of total plan assets. ${ }^{13}$ In addition, 401(k) plans are often not intended to be used as explicit vehicles for employee ownership but rather as vehicles to facilitate retirement planning. This is evidenced by the observation that $401(\mathrm{k}) \mathrm{s}$ typically have multiple investment options that employees can choose from, of which investing in the firm's stock may or may not be an option. ${ }^{14}$

Further, ESOPs allow companies to contribute money to a trust to buy their employees company shares. Thus workers gain an ownership stake without investing their own money to buy employer stock. In contrast, the investments and investment decisions that drive the asset distribution in 401(k) plans are made by the firm's employees. In other words, the levels of ownership in employer stock in 401(k) plans are driven by employee characteristics (such as an employee's level of risk aversion) and not necessarily management's desire to align employer and employee objectives.

Finally, qualified ESOPs must meet non-discrimination tests regarding (a) coverage and (b) non-discrimination in plan features. The non-discrimination requirement stipulates that "highly compensated" employees cannot account for more than $30 \%$ of participants in the ESOP. ${ }^{15}$ This restriction precludes managers from holding the majority of ESOP assets as

\footnotetext{
${ }^{12}$ The survey is available at http://www.nceo.org/main/article.php/id/2/.

${ }^{13}$ Estimates from a sample of 401(k) plans assessed in Cohen (2009) suggest that average 401(k) investments in company stock funds as a percentage of total plan assets equal $17.30 \%$.

${ }^{14}$ For example, Huberman and Jiang (2006) document a range of 4-59 investment fund options in their sample of 401(k) plans.

${ }^{15}$ ERISA, the Employee Retirement Security Act of 1974, and successive Congressional revisions of the Act and related regulations have sought to ensure that neither a top employee group based on those who are highly
} 
managers are among the most "highly compensated" employees in the firm. Thus we are fairly comfortable in suggesting that an investment in an ESOP represents employee stock ownership for non-manager employees as opposed to stock ownership for managers. This is potentially important, as the mechanism through which stock ownership influences disclosure quality is ambiguous if the stock is owned by executives as opposed to non-manager workers.

\section{Employee Negotiation Leverage}

To proxy for employee negotiation leverage, and correspondingly the employee base's ability to extract above-market rents from the firm, we utilize data from the Union Membership and Coverage Database. The database, compiled from the Current Population Survey (CPS), provides private and public sector labor union membership, coverage, and density estimates. The CPS represents a joint effort conducted by the Bureau of Labor Statistics and the Census Bureau, and provides data on the union density of a firm's industry for our sample and control firms. Unionization rate is defined as the number of unionized workers in the firm's industry as a percentage of all the employees in the firm's industry. ${ }^{16}$ The Union Membership and Coverage Database calculates the percentage based on 3-digit SIC industry codes through 2002 and 6-digit NAICS industry codes after 2002. Because the data are updated annually, we update the variable for every firm in the sample and control groups each year.

compensated nor a top employee group based on those who are officers or major stockholders in the firm, benefit from ESOPs more than non-manager employees. In general, these rules ensure that a majority of the benefits in an ESOP are equitably shared among the broader group of non-manager employees.

${ }^{16}$ The use of unionization at the industry-level, as opposed to the firm-level, is supported by prior literature which suggests that the pressure of unions is not limited to their own firms but spills over to other firms in the same industry (e.g., Rosen 1969). The magnitude of this industry spill-over effect appears to empirically dominate the firm-specific direct effect (e.g., Bronars, Deere, and Tracy 1994). 


\section{Research Design}

\subsection{Matched Sample Design}

An important feature of our study is the use of a matched sample design, whereby we match firms with ESOPs with non-ESOP firms. ${ }^{17}$ We use this approach to control for other factors associated with the adoption of ESOP plans. That is, while we argue that firms initiate ESOPs in order to align the objectives of employees with employers, there are also other reasons why a firm might choose to initiate an ESOP (see Freeman and Kleiner 1990; Blasi and Kruse 1991; Beatty 1994; Kruse 1996). First, firms may adopt ESOPs because they are facing liquidity constraints and cannot afford to compensate employees with cash. Second, firms may adopt ESOPs as a response to hostile takeover threats. Third, firms may adopt ESOPs out of a desire to discourage unionization by increasing employee identification with the company. These other incentives to adopt ESOPs inform our choices when selecting parameters to create a matched non-ESOP control group. Specifically, for our main tests we match the ESOP group to a nonESOP control group by the following parameters: fiscal year, industry (two-digit SIC codes), and firm size. ${ }^{18}$ By using these matching parameters (as well as several alternative matching procedures described below), we mitigate concerns that omitted correlated variables related to alternate reasons for adopting an ESOP are driving our results. However, we note both that our multivariate tests include numerous control variables motivated by prior research and that our robustness section provides several additional tests (including alternative matching procedures, propensity score matching tests, a Heckman self-selection test, non-matching based results,

\footnotetext{
${ }^{17}$ Heckman et al. (1997; 1998), Li and Prabhala (2007), and Lawrence et al. (2011) provide theoretical support for matching as an econometric technique for addressing endogeneity.

${ }^{18}$ For example, evidence suggests that the environment for corporate takeovers is similar across firms of similar sizes in the same industry in the same year (e.g., Palepu 1986). Additionally, Bova (2010) illustrates that union representation is clustered by industry. The evidence suggests that the existence of a unionized employee base is either homogenous or next to non-existent across firms in the same industries, where industries are defined by twodigit SIC code.
} 
changes tests, tests for alternative explanations, and effects related to Reg FD) to help further reduce the likelihood that these alternate motivations for establishing an ESOP are correlated factors in our results.

\subsection{Regression Models}

We test whether voluntary disclosure is higher for firms with employee ownership by running the following regression:

$$
D_{I S C} C_{i t}=\alpha_{0}+\beta_{1} E_{S O P}+\beta_{2} U N I O N R_{i t}+\beta_{3} E_{S O P} \times U N I O N R_{i t}+\gamma C O N T R O L S+\varepsilon_{i t}
$$

In the above regression equation, DISC is either one of our nine disclosure proxies or the aggregate disclosure score. Note that when $M F$ and $C C$ are dependent variables, we use Probit estimation clustered by firm. Because of skewness in the data, for $N M F, N G M F, N B M F, M F S$, and NCONFC, we take the log of one plus the number (as in Francis et al. 2008), and then use OLS clustered by firm. Finally, for annual report readability and the aggregate disclosure score, we use OLS clustered by firm. ${ }^{19}$

As defined in Section 3, ESOP is an indicator variable which equals one if the firm has an ESOP in a given year and zero otherwise, and UNIONR is the union density of the firm's industry for a given year. For our guidance and conference call tests, we base our choice of control variables (CONTROLS) on prior research (Hilary 2006; Chen et al. 2008; Francis et al. 2008). Specifically, we include controls for firm size (SIZE); an indicator variable equal to one for industries with high litigation risk (SIC codes 2833-2836, 3570-3577, 7370-7374, 3600-3674, 5200-5961, 8731-8734) and zero otherwise (LIT); financial leverage (LEV); sales growth (GROWTH); return on assets $(R O A)$; an indicator variable equal to one if the firm has a seasoned

\footnotetext{
${ }^{19}$ For the count data $(N M F, N G M F, N B M F, M F S$, and $N C O N F C)$, we have alternatively used negative binomial regression clustered by firm. The results are very similar and no inferences are affected.
} 
equity offering during the year and zero otherwise $(S E O)$; an indicator variable equal to one if the firm engages in a merger and acquisition as per the SDC Platinum M\&A database, zero otherwise (MA); standard deviation of operating earnings in the last five years (EARNVOL); and the number of analysts following the firm as per IBES (ANALYFOL). Finally, to ensure that results are not driven by omitted industry-level factors, we control for industry competition using the Herfindahl index of a firm's industry (HERFIN) and for industry profitability using the median industry-level return on assets (IROA).

For the annual report readability tests, we follow $\mathrm{Li}$ (2008) and include SIZE; GROWTH; firm age (AGE); special items scaled by total assets (SI); EARNVOL; number of business segments (NBSEG); number of geographic segments (NGSEG); SEO; MA; HERFIN, IROA, and an indicator variable equal to one if the firm is incorporated in Delaware, zero otherwise $(D L W)$. All regression models also include year fixed effects. ${ }^{20}$

\section{Sample and Correlations}

\subsection{Sample and Descriptive Statistics}

We summarize our sample selection procedure in Panel A of Table 1. The main constraint on our sample size is the availability of ESOP data. After requiring data on ESOPs, our matching dimensions, and control variables, we have matched pair samples of 5,041 for guidance and conference call based tests (Table 3), and 4,197 for annual report readability tests (Table 4). Our sample is quite evenly spread across our sample period, 1999 - 2007 (Panel B). The sample is also spread across a number of industries, with the exceptions of the strong representation from Electric, Gas, \& Sanitary Services (17.53\%) and Chemical \& Allied Products (10.52\%). Table 2, Panel A (B) provides descriptive statistics for the dependent, test,

\footnotetext{
${ }^{20}$ For tests using DSCORE, we include all control variables from the other regressions tests.
} 
and control variables used for the ESOP (non-ESOP) firms. All variables are defined in the Appendix. We note that the samples are well matched on size and unionization rates (in addition to industry and year by definition). Relative to non-ESOP firms, ESOP firms are less leveraged, more profitable, less volatile in operating earnings, and experience lower growth. Our multivariate tests include controls for these firm characteristics and in sensitivity analyses we also explicitly match on these firm characteristics.

\subsection{Correlations}

Table 2, Panel C presents Pearson correlations among the dependent and test variables. Spearman correlation results are similar and are not tabulated for brevity. Most importantly, we note that employee ownership (ESOP) is positively and significantly (at the one percent level) correlated with all ten disclosure proxies. There is no significant correlation between ESOP and the unionization rate $(U N I O N R),{ }^{21}$ and $U N I O N R$ is negatively correlated with all disclosure proxies. These correlation coefficients are consistent with $\mathrm{H} 1$ and $\mathrm{H} 2$.

As expected, the five management guidance variables are all highly correlated; however, as the correlation coefficients are below one, they still capture somewhat different dimensions of guidance. The guidance measures are also positively correlated with the conference call measures. In contrast, the two readability measures exhibit either insignificant or negative correlations with the other disclosure proxies, consistent with readability representing a notably different dimension of financial transparency than the other disclosures. ${ }^{22}$ As correlation results

\footnotetext{
${ }^{21}$ Since we match the ESOP firms with non-ESOP firms by year, two-digit SIC code, and size, and UNIONR are calculated for each 3-digit SIC industry, it is unsurprising that unionization rates are unrelated to ESOP.

${ }^{22}$ For brevity we do not tabulate correlation coefficients for control variables. Untabulated statistics show that the highest correlations are between firm size and analyst following (0.77), unionization rate and high-litigation industries (0.51), and number of management forecast and analyst following (0.44). Note, however, that variance inflation factors do not suggest that multicollinearity is an issue in our multivariate tests (i.e., no VIFs are larger than
} 
do not control for differences in firm or industry characteristics, we now turn to multivariate tests.

\section{Empirical Results}

\subsection{Primary Tests}

As discussed in Section 4, we base our choice of control variables on prior research, which suggests that a different set of controls may be appropriate for guidance and conference calls compared with readability. Thus, we report regression results for guidance and conference calls together in Table 3 and for readability in Table 4.

We first report results for disclosure regressed on employee ownership (ESOP) and the unionization rate in the firm's industry (UNIONR). The adjusted (or pseudo) $\mathrm{R}^{2} \mathrm{~s}$ of these models range from $17 \%$ to $49 \%$. Panel A of Table 3 shows that, several of the control variables are significantly associated with discretionary disclosure. For example, consistent with prior research, ROA, M\&A activities, and analyst following are all consistently positively and significantly correlated with disclosure.

More importantly, the table shows that, relative to a matched sample of non-ESOP firms, employee ownership (ESOP) is positively and significantly (at the ten percent level or better using a two-tailed test) related to firm-provided voluntary disclosure. This result is consistent with $\mathrm{H} 1$, holds for all seven guidance and conference call disclosure proxies, and is robust to the inclusion of an extensive set of control variables motivated by prior research. In addition to being

five). Nevertheless, we have reestimated the regressions after excluding each of these controls one at a time and no inferences are affected. 
statistically significant, the effect is also economically meaningful. For example, firms with ESOPs issue 0.4 more management earnings forecasts than do non-ESOP firms. ${ }^{23}$

Second, the estimated coefficient on UNIONR is negative and significant at the five percent level in all models. These findings (which support H2) suggest that firms respond to stronger bargaining power from employees by suppressing financial information. This finding is in line with the proprietary cost hypothesis tested in prior research (e.g., Bens et al. 2010). Thus, using both a recent and large sample of firms, we complement and extend prior research by (1) showing this relation for a large set of voluntary disclosure metrics (i.e., increasing the generalizability of the result), (2) simultaneously testing for the effects of labor power and employee ownership (i.e., a potentially omitted variable in prior research), and (3) drawing explicit conclusions about a firm's incentive to keep information opaque by looking directly at voluntary disclosure proxies, as opposed to implicit conclusions drawn from market proxies for information asymmetry.

In Panel B we complete the model by adding the interaction effect between employee ownership and labor negotiation leverage. The estimated coefficients on UNIONR continue to be negative and significant. Directly related to $\mathrm{H} 3$, the interaction term is positively and significantly associated with all disclosure proxies examined. The main effect of ESOP is no longer statistically significant, suggesting that employee ownership is important, but especially through its effect in mediating the negative effect of proprietary costs related to employee negotiation power. These findings support H3 and highlight the importance of investigating employee ownership and employee bargaining power jointly.

\footnotetext{
${ }^{23}$ The mean of NMF is 2.6 for the entire sample. Thus, $\frac{\partial L O G N M F}{\partial E S O P}=\frac{1}{1+N M F} \frac{\partial N M F}{\partial E S O P}=0.107 \Rightarrow \frac{\partial N M F}{\partial E S O P}=(1+2.6) \times 0.107=0.385$
} 
Table 4 shows the results of the annual report readability tests. The findings are similar to those reported in Table 3. That is, the disclosure levels using both FOGINV and LENGTHINV are increasing in employee ownership, and this finding is robust to including both UNIONR and the interaction term between ESOP and UNIONR (columns 3 and 4). Further, UNIONR is negatively associated with both FOGINV and LENGTHINV (with greater significance levels for the latter ${ }^{24}$ ). Finally, while there is no evidence of a statistically significant interactive effect between employee ownership and the degree of unionization when assessing readability as a dependent variable, the interaction term is signed in accordance with our prediction. We conclude based on these results that there is strong evidence that employee ownership is associated with readability. Further, consistent with the guidance and conference call results, there is also a significant negative effect of unionization on readability (consistent with the proprietary cost hypothesis).

Finally, Table 5 repeats the analyses using the aggregate disclosure score (DSCORE), and includes all control variables employed in tables 3 and 4 . The findings are similar to those reported in Table 3 and provide further support for our hypotheses. Taken together, across our ten disclosure proxies, we find evidence that a firm's incentive to disclose information is increasing with employee ownership and decreasing in employee bargaining power. The general tenor of the results additionally suggests that employee ownership's role in improving transparency is larger, the greater the bargaining power of a firm's employees.

\footnotetext{
${ }^{24}$ Whereas the LENGTHINV regressions have adjusted $\mathrm{R}^{2}$ of about $26 \%$, the $\mathrm{R}^{2}$ for FOGINV is around $6 \%$ (consistent with the results in Table 2 of Li 2008). Thus it is possible that the LENGTHINV regressions are better specified.
} 


\subsection{Market Outcome Tests}

Hilary (2006) finds that higher unionization rates are associated with larger information asymmetries with the market. Specifically, Hilary (2006) observes that a firm's bid-ask-spread and PIN measure are increasing in the union density of the firm's industry. If employee ownership has a greater effect on improving disclosure the greater the firm's union density, we should also observe that employee ownership mitigates a firm's information asymmetries with the market, the greater the union density of its industry. Using our main model and separately incorporating a firm's bid-ask-spread and PIN measure as dependent variables, we rerun our main analysis. ${ }^{25}$ Focusing on the interaction between ESOP and UNIONR, Table 6 illustrates that as union density increases, ESOP firms are more likely to have smaller bid-ask-spreads and PIN measures. These results provide further support consistent with our hypotheses and are consistent with ESOPs mitigating the incentive to keep information asymmetric, the greater employees' negotiation power.

\subsection{Further Endogeneity Tests}

It is important for our study to address issues related to potential endogeneity of employee ownership. In our main tests, we use a matched firm design and we consider this a strength of our research design (e.g. Li and Prabhala 2007). ${ }^{26}$ In addition, we include a large number of control variables motivated by prior research. Equally importantly, we test for an interaction effect. As Rajan and Zingales (1998) emphasize, focusing on interaction terms makes it more difficult to envision a consistent theory in which causality is reversed yet the subsample

\footnotetext{
${ }^{25}$ Please see the Appendix for definitions of these variables.

${ }^{26}$ However, we have also performed a test in which we abandon matching completely and instead include all Compustat firms with available data in our sample and use an indicator variable to denote ESOP firms. This specification has the advantage of significantly increasing the sample size (e.g., $\mathrm{N}=23,475$ for tests using DSCORE which require data on all control variables). Results are similar to those reported with one exception. With this specification, the main effect of ESOP is positive and significant at the five percent level (using a two-tailed test) also after including $U N I O N R$ and $E S O P \times U N I O N R$.
} 
results hold. Nevertheless, we conduct additional tests to mitigate the possibility that our results are affected by endogeneity. Specifically, we conduct several alternative matching-based tests (both attribute matching and propensity score matching), a Heckman self-selection test, and a changes test. We discuss our alternate methods to address endogeneity below.

\section{Alternative Attribute-Based and Propensity Score Matching Tests (Untabulated)}

First, we employ alternative but similar attribute-based matching procedures as those used in the tabulated results. Specifically, based on the descriptive statistics presented in Table 2, we match the ESOP group to a non-ESOP control group by fiscal year, industry (two-digit SIC codes), and one of three firm characteristics: leverage, ROA, or growth (while still including the full set of control variables). We find that results are very similar to those reported in the paper.

In a second test, instead of using the standard one-to-one matched design most often employed in accounting research, we use a one-to-many design. The idea behind this procedure is that it may reduce noise in the matched sample (e.g., Cram et al. 2009). In particular, we match our ESOP firms to five rather than one firm. ${ }^{27}$ Results are similar and slightly stronger using this approach.

Third, as an alternative to traditional matching techniques, we employ propensity score matching (PSM). PSM is an econometric method that allows for efficient matching of treatment firms with a set of control firms (Rosenbaum and Rubin 1983). Specifically, PSM matches based on a "propensity score" - defined as the probability that the firm is in the treatment group conditional on the observed firm variables. We conduct the following test: We first estimate the

\footnotetext{
${ }^{27}$ For each ESOP firm, we first find its corresponding non-ESOP group by year and two-digit SIC industry. Then within this group, we calculate the absolute values of the difference in firm size between the ESOP firm and nonESOP firms. We pick five non-ESOP firms with the lowest absolute values of the difference for each ESOP firm. Once a non-ESOP firm is picked for an ESOP firm as a control, it still can be picked for other ESOP firms (i.e., sampling with replacement). Using this approach, the sample size is $11,107$.
} 
Probit model using the entire Compustat sample with ESOP as the dependent variable, and SIZE, GROWTH, ROA, LEV, and year and industry indicators as independent variables to obtain the propensity scores. We then require our control firms to have the same fiscal year and industry as our treatment firms. Within this group we pick control firms based on propensity scores. Untabulated statistics show that we obtain a well-balanced sample with this approach, and results are very similar to those reported earlier.

\section{Heckman Self-Selection Test}

As an alternative method to address endogeneity, we also provide results using the Heckman (1979) approach. In the first-stage equation, we model the decision to adopt employee ownership plans. We control for SIZE, LEV, GROWTH, ROA, UNIONR, and MA. As our instrument for ESOP we use the effective tax rate based on cash payments of tax, CASHETR (this instrument is motivated by Dyreng et al. 2008). CASHETR is strongly positively correlated with ESOP but is uncorrelated with DSCORE.

The first-stage results are presented in column 1 of Table 7, Panel A. ESOP is significantly positively related to SIZE and ROA (in addition to CASHETR) and is significantly negatively associated with $L E V$ and GROWTH. More importantly, the second stage regression shows that, after controlling for the Inverse Mills ratio, we continue to find support for our hypotheses.

\section{Changes Test}

We reexamine the relation between employee ownership and voluntary disclosure using a change specification. Although our main interest is in comparing ESOP and non-ESOP firms, the 
alternative analysis can help us in mitigating possible concerns regarding correlated omitted variables and direction of causality. Specifically, we first identify firms that have no ESOPs at year $t-1$ and initiate at least one ESOP in year $t$ and keep them in year $t+1$ during our sample period. Then we take data for firm $i$ at year $t+1$ and at year $t-1$, and take the difference. The intercept is differenced out, leaving $I N I T=1$ for all the firms. We put an extra initial "D" for our dependent variable (DSCORE), and other independent variables to indicate the change specification. ${ }^{28}$ Even in this relatively small sample $(\mathrm{N}=157)$, we observe a statistically significant and economically meaningful estimated coefficient on INIT (see Table 7, Panel B). This finding supports our main hypothesis and also mitigates the possibility of "some other factor" explaining our previously reported results.

In sum, we conclude that our results are robust to controls for endogeneity of employee ownership using a variety of tests and specifications.

\subsection{Other Robustness Tests}

\section{A Continuous Proxy for Employee Ownership}

We replace the binary ESOP variable from our main analyses with a continuous variable for employee ownership, ESOPHPE - the average assets held per participant in the ESOP plan taken from the Form 5500 filings. We argue that the alignment between employees and shareholders should be increasing in ESOPHPE, as the higher the equity stake per participant, the greater the goal alignment between employees and shareholders. Replacing ESOP with ESOPHPE, we rerun our main analysis using DSCORE as a dependent variable. The results echo our prior findings. Panel A of Table 8 reveals that unionized firms are more likely to have an opaque disclosure policy and that this tendency is mitigated as ESOPHPE increases. The

\footnotetext{
${ }^{28}$ As there is no meaningful variation in industry unionization rates over such a small period, this sensitivity analysis focuses solely on employee ownership.
} 
evidence is consistent with the notion that the ESOP variable proxies for the alignment between non-manager employees and shareholders and that this alignment is driving our results in the main model.

\section{Other Reasons to Adopt an ESOP}

In a recent study, Kim and Ouimet (2009) argue that, outside of aligning the goals of employees with those of management, firms may also adopt ESOPs to either (1) form management-worker alliances as in Pagano and Volpin (2005), wherein management bribes workers to garner worker support in thwarting hostile takeover threats, or (2) to substitute wages with ESOP shares when the firms is cash constrained. It is possible that either of these motivations might also be correlated with management's incentive to disclose more. Kim and Ouimet (2009) argue that firms that have ESOPs containing more than 5\% of the firm's outstanding shares are likely candidates to pursue ESOPs for reasons consistent with points (1) and (2). To ensure that our results are not being spuriously driven by management's incentive to either fight hostile takeovers or provide an alternate means of compensation when facing cash flow constraints, we rerun our analysis and remove all firms with ESOPs that contain over 5\% of the firm's stock. ${ }^{29}$ For brevity we only tabulate results for DSCORE and report the results of these tests in Panel B of Table 8. The results are very similar to those shown in Table 5 and suggest that our inferences are not unduly affected by the factors examined by Kim and Ouimet (2009).

\footnotetext{
${ }^{29}$ Untabulated statistics show that the median and mean values for employee ownership are $3.7 \%$ and $6 \%$, respectively.
} 


\section{Effect of Reg FD}

We hypothesize that management's incentive to keep information opaque with the market is likely to be different in the periods prior to and after the inception of Regulation FD (Reg FD). Prior to Reg FD, managers could maintain an informational advantage over their employees by not only curtailing public disclosure, but by also engaging in private communications with analysts. Thus, pre-Reg FD, managers had an alternate route to keep information asymmetric with employees if they decided to forgo the strategy of an opaque disclosure policy. However, managers no longer have the ability to communicate privately with analysts, post-Reg FD (e.g., Herrmann et al. 2008). Thus, post-Reg FD, managers should have a larger incentive to utilize an opaque disclosure policy in order to maintain their informational advantage over employees. It follows that the results of our paper should be stronger, post-Reg FD. In Panel C of Table 8, we partition the sample into a pre-Reg FD subsample and a post-Reg FD subsample. To make the sample size more comparable, we only use the data leading up to 2002 for the post-Reg FD subsample. Consistent with our predictions, we find that the coefficients of interest are signed correctly, larger in magnitude, and more significant in the post-Reg FD partition. We believe that these results further strengthen the inferences drawn in our study.

\section{Other Sensitivity Analyses (Untabulated)}

We first control for matched pair fixed effects. Second, we control for stock ownership by the top five executives using data from ExecuComp (which reduces the sample to 2,605 observations). The results from these sensitivity analyses are similar to those reported and no inferences are affected. 


\section{Concluding Remarks}

Research suggests that both the firm and, more broadly, other market participants such as the firm's employees are impacted by the effects of employee ownership. In this study, we examine how employee ownership affects firms' voluntary disclosure choices. We contribute to the literature by simultaneously examining the role of employee ownership (alignment effect) and employee negotiation leverage (rent extraction effect) on corporate disclosure. To our knowledge, this is the first study to attempt such a joint investigation. In addition, we use a broad array of disclosure proxies in order to capture the multidimensional aspects of both the quality and quantity of voluntary disclosure. Using multiple disclosure proxies improves the generalizability of our results and mitigates the possibility that some "other factor" explains our results.

Our empirical tests are based on matching firms with employee ownership (ESOP firms) with non-ESOP firms. Our main findings are that employee ownership is strongly positively related to financial transparency, and that the effect of employee ownership on disclosure is increasing when employee negotiation power is strong. In contrast, transparency is decreasing in employee negotiation leverage (i.e., unionization rates), consistent with the proprietary cost hypothesis. More broadly, the study identifies a novel capital market benefit to firms' utilizing employee ownership. Specifically, a firm's use of an employee stock ownership plan appears to benefit the firm by not only aligning goals between the firm and its employees, but by also increasing disclosure from the firm to all of its stakeholders by mitigating the firm's need to keep information opaque.

A standard caveat in this line of research is that it is difficult to prove causality. However, we take some comfort in the fact that our empirical results are supported by economic theory. 
Further, as detailed in the paper, we employ research design features that increase our confidence in the inferences drawn. In addition to using several alternative variations of matched attribute sample design, we include numerous control variables motivated by prior research, use propensity score matching, and a Heckman self-selection model. We also report results of changes tests in addition to association tests. Finally and importantly, we focus on an interaction effect, which alleviates concerns over potential omitted variables. 


\section{REFERENCES}

Baginski, S.P., J.M. Hassell, and M.D. Kimbrough. 2004. Why do managers explain their earnings forecasts? Journal of Accounting Research 42 (1): 1-29.

Beatty, A. 1994. An empirical analysis of the corporate control, tax and incentive motivations for adopting leveraged employee stock ownership plans. Managerial and Decision Economics. 15 (4): 299-315.

Bens, D.A., P.G. Berger, and S.J. Monahan. 2010. Discretionary disclosure in financial reporting: An examination comparing internal firm data to externally reported segment data. Forthcoming, The Accounting Review.

Beyer, A., D.A. Cohen, T.Z. Lys, and B.R. Walther. 2010. The Financial Reporting Environment: Review of the Recent Literature. Forthcoming, Journal of Accounting and Economics.

Biddle, G.C., G. Hilary, and R.S. Verdi. 2009. How does financial reporting quality relate to investment efficiency? Journal of Accounting and Economics 48 (2-3): 112-131.

Blasi, J. and P. Kruse. 1991. The New Owners: The Mass Emergence of Employee Ownership in Public Companies and What it Means to American Business. New York: HarperBusiness.

Botosan, C. 1997. Disclosure level and the cost of equity capital. The Accounting Review 72 (3): 323-349.

Bova, F. 2010. Labor unions and management's incentive to signal a negative outlook. Working paper, University of Toronto.

Bowen, R., A. Davis, and D. Matsumoto. 2002. Do conference calls affect analysts' forecasts? The Accounting Review 77 (2): 285-316.

Bowen, R.M., L. DuCharme and D. Shores. 1995. Stakeholders' implicit claims and accounting method choice. Journal of Accounting and Economics 20 (3): 255-295.

Bronars, S., D. Deere, and J. Tracy. The effects of unions on firm behavior: An empirical analysis using firm-level data. Industrial Relations 33 (4): 426 - 445.

Brown, S., S.A. Hillegeist, and K. Lo. 2004. Conference calls and information asymmetry. Journal of Accounting and Economics 37 (3): 343-366.

Bushee, B., D. Matsumoto, and G. Miller. 2003. Open versus closed conference calls: The determinants and effects of broadening access to disclosure. Journal of Accounting and Economics 34 (1-3): 149-180.

Bushee, B., D. Matsumoto, and G. Miller. 2004. Managerial and investor responses to disclosure regulation: The case of Reg FD and conference calls. The Accounting Review 79 (3): 617-643.

Chen, S., X. Chen, and Q. Cheng. 2008. Do family firms provide more or less voluntary disclosure? Journal of Accounting Research 46 (3): 499-536.

Cohen, L. 2009. Loyalty-based portfolio choice. Review of Financial Studies 22 (3): 1213-1245.

Coller, M., and T. L. Yohn. 1997. Management forecasts and information asymmetry: an examination of bid-ask spreads. Journal of Accounting Research 35 (2): 181-191.

Cram, D.P., V. Karan, and I. Stuart. 2009. Three Threats to Validity of Choice-based and MatchedSample Studies in Accounting Research. Contemporary Accounting Research 26 (2): 477-516.

Cramton, P., H. Mehran, and J. Tracy. 2008. ESOP fables: The impact of employee stock ownership plans on labor disputes. FRB of New York Staff Report. No. 347.

Croson, R. T. A. 1996. Information in ultimatum games: An experimental game. Journal of Economic Behavior and Organization 30: 197-212.

Cukierman, A., A.H. Meltzer. 1986. A theory of ambiguity, credibility, and inflation under discretion and asymmetric information. Econometrica 54: 1099-1128.

Darrough, M. 1993. Disclosure policy and competition: Cournot vs. Bertrand. The Accounting Review 68: 534-561.

De Franco, G., O.-K. Hope, and S. Larocque. 2010. The Effect of Disclosure on the Pay-Performance Relation. Working paper, University of Toronto and University of Notre Dame. 
Dou, Y., O.-K. Hope, and W.B. Thomas. 2010. Relationship-specificity, contract enforceability, and income smoothing: an international study. Working paper, University of Toronto and University of Oklahoma.

Dye. R. 1985. Disclosure of non-proprietary information. Journal of Accounting Research 23 (1):123145.

Dyreng, S.D., M. Hanlon, and E.L. Maydew. 2008. Long-Run Corporate Tax Avoidance. The Accounting Review 83 (1): 61-82.

Francis, J., D.J. Nanda, and P. Olsson. 2008. Voluntary disclosure, earnings quality, and cost of capital. Journal of Accounting Research 46 (1): 53-99.

Frankel, R., M. Johnson, and D. Skinner. 1999. An empirical examination of conference calls as a voluntary disclosure medium. Journal of Accounting Research 37 (1): 133-150.

Freeman, R., and M. Kleiner. 1990. The impact of new unionization on wages and working conditions. Journal of Labor Economics 8 (1): S8-S25.

Frost, A. C. 2000. Explaining variation in workplace restructuring: The role of local union capabilities. Industrial and Labor Relations Review 53: 559-578.

Graham, J., C.R. Harvey, and S. Rajgopal. 2005. The economic implications of corporate financial reporting. Journal of Accounting and Economics 40 (1-3): 3-73.

Healy, P.M., A. Hutton, and K.G. Palepu. 1999. Stock performance and intermediation changes surrounding sustained increases in disclosure. Contemporary Accounting Research 16 (3): 485520.

Heckman, J.J. 1979. "Sample selection bias as a specification error." Econometrica Vol. 47 No. 1: 153162.

Heckman, J.J., H. Ichimura and P.E. Todd. 1997. Matching as an Econometric Evaluation Estimator: Evidence from Evaluating a Job Training Programme. The Review of Economic Studies Vol. 64 No. 4 Special Issue: 605-654.

Heckman, J.J., H. Ichimura and P.E. Todd. 1998. Matching as an Econometric Evaluation Estimator. The Review of Economic Studies Vol. 65 No. 2: 261-294.

Herrmann, D.R., O.-K. Hope, and W.B. Thomas. 2008. International Diversification and Forecast Optimism: The Effects of Reg FD. Accounting Horizons 22 (2): 179-197.

Hilary, G. 2006. Organized labor and information asymmetry in the financial markets. Review of Accounting Studies 11 (4): 525-548.

Hirst, E., L. Koonce, and S. Venkataraman. 2008. Management earnings forecasts: A review and framework. Accounting Horizons 22 (3): 315-338.

Huberman, G. and W. Jiang. 2006. Offering versus choice in 401(k) plans: equity exposure and number of funds. Journal of Finance 61 (2): 763-801.

Hutton, A., G. Miller, and D. Skinner. 2003. The role of supplementary statements with management earnings forecasts. Journal of Accounting Research 41 (5): 867-90.

Jones, D.C., and T. Kato. 1995. The productivity effects of employee stock-ownership plans and bonuses: evidence from Japanese panel data. American Economic Review 85 (3): 391-414.

Jovanovic, B. 1982. Truthful disclosure of information. Bell Journal of Economics 13 (1):36 -44.

Jung, W and Y. Kwon. 1988. Disclosure when market is unsure of information endowment of managers. Journal of Accounting Research 26 (1): 143 - 153.

Kim, E.H., and P.P. Ouimet. 2009. Employee capitalism or corporate socialism? Broad-based employee stock ownership. Working paper, University of Michigan and University of North Carolina.

King, R., G. Pownall, and G. Waymire. 1990. Expectations adjustments via timely management forecasts: Review, synthesis, and suggestions for future research. Journal of Accounting Literature 9: 113144.

Kochan, T. A., and H.C. Katz. 1988. Collective bargaining and industrial relations (2nd ed.). Homewood, IL: Irwin.

Kruse, P. 1996. Why do Firms adopt profit-sharing and employee ownership plans? British Journal of Industrial Relations. 34 (4): 515-38. 
Kruse, P., J. Blasi, and, and R. Park. 2009. Chapter 1: Shared Capitalism in the US Economy: Prevalence, Characteristics, and Employee Views of Financial Participation in Enterprises. Shared Capitalism at Work: Employee Ownership, Profit and Gain Sharing, and Broad-based Stock Options University of Chicago Press.

La Porta, R., Lopez-de-Silanes, F., Shleifer, A, and Vishny, R. 1997. Legal determinants of external finance. Journal of Finance 52 (3): 1131-150

Lang, M., and R. Lundholm. 1996. Corporate disclosure policy and analysts behavior. The Accounting Review 71(4): 467-492.

Lawrence, A. 2010. Individual Investors and Financial Disclosure. Working paper, University of Toronto.

Lawrence, A., M. Minutti-Meza, and P. Zhang. 2011. Can Big 4 versus non-Big 4 differences in auditquality proxies be attributed to client characteristics? The Accounting Review 86 (1): 259-286.

Leap, T. L. 1991. Collective bargaining and labor relations (2nd ed.). New Jersey: Prentice Hall, Englewood Cliffs.

Li, F. 2008. Annual report readability, current earnings, and earnings persistence. Journal of Accounting and Economics 45 (2-3): 221-247.

Li, K., and N.R. Prabhala. 2007. Self-Selection Models in Corporate Finance. Chapter 2 in: Handbook of Corporate Finance: Empirical Corporate Finance. Handbooks in Finance Series, Elsevier/North Holland.

Marquardt, C.A., and C.I. Wiedman. 1998. Voluntary disclosure, information asymmetry, and insider selling through secondary equity offerings. Contemporary Accounting Research 15 (4): 505-537.

McDonald, I. and R. Solow. 1981. Wage bargaining and employment. The American Economic Review 71 (5): 896-908.

Nagar, V., D. Nanda, and P. Wysocki. 2003. Discretionary disclosures and stock-based incentives. Journal of Accounting and Economics 34: 283-309.

Pagano, M., and P. F. Volpin. 2005. Managers, workers, and corporate control. Journal of Finance 60 (2):841-868.

Palepu, K.G. 1986. Predicting takeover targets: a methodological and empirical analysis. Journal of Accounting and Economics 8 (1): 3-35.

Rajan, R.G., and L. Zingales. 1998. Financial dependence and growth. American Economic Review 88 (3): 559-586.

Raman, K., and H. Shahrur. 2008. Relationship-specific investments and earnings management: evidence on corporate suppliers and customers. The Accounting review 83 (4): 1041-1081.

Reynolds, L. G., S. H. Masters, and C.H. Moser. 1998. Labor economics and labor relations $\left(11^{\text {th }} \mathrm{ed}.\right)$. New Jersey: Prentice Hall.

Rogers, J.L., and A. Van Buskirk. 2009. Shareholder litigation and changes in disclosure behavior. Journal of Accounting and Economics 47 (1-2): 136- 156.

Rosen, S. 1961. Trade union power, threat effects, and the extent of organization. The Review of Economic Studies 36 (2): 185 - 196.

Rosenbaum, P.R., and D.R. Rubin. 1983. The central role of the propensity score in observational studies for causal effects. Biometrika 70 (1): 41-55.

Schock, L. J. 2007. Speech by SEC staff: feedback from individual investors on disclosure (January 19, 2007). Available at http://www.sec.gov/news/speech/2007/spch011907ljs.htm.

Scott, T. 1994. Incentives and disincentives for financial disclosure: Voluntary disclosure of defined benefit pension plan information from Canadian firms. The Accounting Review 69 (1): 26-43.

Securities and Exchange Commission. 1998. A Plain English Handbook: How to Create Clear SEC Disclosure Documents. U.S. Securities and Exchange Commission, Washington, D.C.

Verrecchia, R. E. 2001. Essays on disclosure. Journal of Accounting and Economics 32 (1-3): 97-180. 
APPENDIX

\begin{tabular}{|c|c|}
\hline Variable & Definition (Compustat variables in parentheses) \\
\hline \multicolumn{2}{|l|}{ Test variables } \\
\hline ESOP & $\begin{array}{l}\text { Indicator variable that takes the value of one if a firm has at least one } \\
\text { employee stock ownership plan (ESOP) that particular year, and zero } \\
\text { otherwise (Form 5500). }\end{array}$ \\
\hline INIT & $\begin{array}{l}\text { Indicator variable that takes the value of one if a firm adopted employee } \\
\text { stock ownership plans (ESOPs) the previous year and still has them the } \\
\text { current year, and zero otherwise. }\end{array}$ \\
\hline ESOPHPE & Natural Logarithm of average participant balance (Form 5500). \\
\hline UNIONR & $\begin{array}{l}\text { Number of workers as union members in a firm's industry as a percentage } \\
\text { of all the employees in the firm's industry (Union Membership and } \\
\text { Coverage Database). }\end{array}$ \\
\hline$E S O P \times U N I O N R$ & The product of ESOP and UNIONR. \\
\hline
\end{tabular}

\section{Disclosure variables}

$M F$

Indicator variable that takes the value of one if managers make at least one earnings forecast that particular year, and zero otherwise (First Call).

$N M F \quad$ Number of management forecasts that particular year.

$L O G N M F=\log (1+N M F)$

NGMF Number of management good news forecasts that particular year. Management forecasts with positive market-adjusted three-day CARs centered on the forecast date are classified as good news forecasts. $L O G N G M F=\log (1+N G M F)$

NBMF Number of management bad news forecasts that particular year. Management forecasts with negative market-adjusted three-day CARs centered on the forecast date are classified as bad news forecasts.

$L O G N B M F=\log (1+N B M F)$

MFS Management forecast score. We assign a value of 0 if the firm provides no forecast, a value of 1 to the purely qualitative forecast (i.e., no point estimate or range is given), a value of 2 to the forecast with a range estimate, and a value of 3 to the forecast with a point estimate. We sum the values over all forecasts made by the firm that particular year.

LOGMFS $=\log (1+M F S)$

CC Indicator variable that takes the value of one if a firm holds at least one conference call that particular year, and zero otherwise (BestCalls.com).

NCONFC Number of conference calls that particular year.

LOGNCONFC $=\log (1+N C O N F C)$

FOGINV A measure of financial statement readability computed following $\mathrm{Li}$ 
(2008) multiplied by -1 .

LENGTHINV Natural logarithm of the number of words following Li (2008) multiplied by -1 .

DSCORE An aggregate disclosure measure. We first normalize all nine proxies above between zero and one and take the average of these nine measures as our summary statistic for financial disclosure.

\section{Consequence variables}

SPREAD

PIN
The bid-ask spread computed as in Hilary (2006) (TAQ).

The probability of informed trading computed following the procedure outlined in Brown, Hillegeist, and Lo (2004) (TAQ).

\section{Control variables}

SIZE

$L E V$

GROWTH

$R O A$

EARNVOL

LIT

SEO

$M A$

AGE

$S I$

NBSEG

$N G S E G$

$D L W$

ANALYFOL HERFIN
Natural logarithm of total assets (at).

The ratio of long-term debt (dltt) to the sum of long-term debt to the book value of equity (ceq).

Current year's growth in sales (sale).

Earnings before extraordinary item (ib) divided by total assets (at) at the beginning of the year.

Standard deviation of the operating earnings (oiadp) scaled by last year total assets (at) over the last five fiscal years.

Indicator variable that takes the value of one if a firm is in industries with high litigation risk (SIC codes 2833-2836, 3570-3577, 7370-7374, 36003674, 5200-5961, 8731-8734), and zero otherwise.

Indicator variable that takes the value of one if a firm has seasoned equity offering that particular year, and zero otherwise (SDC Global New Issues database).

Indicator variable that takes the value of one if a firm engages in a merger and acquisition that particular year, and zero otherwise (SDC Platinum M\&A database).

Number of years since IPO.

Special items scaled by total assets (at).

Number of business segments.

Number of geographic segments.

Indicator variable that takes the value of one if a firm is incorporated in Delaware, and zero otherwise.

Number of financial analysts following the firm that particular year.

The Herfindahl index of firms' sales for each year and 3-digit SIC industry. 
IROA

$N A S D$

PRICE

VOL

STDRET

CASHETR
The median of ROA for each year and 3-digit SIC industry.

Indicator variable that takes the value of one if the stock is traded on the NYSE market, and zero otherwise.

Natural logarithm of stock price at the end of the year.

The yearly median of the 12 monthly volumes (in billions of dollars). The monthly volumes are the median of daily trading volumes.

The standard deviation of the daily returns calculated for each firm and each year.

The long-run cash effective tax rate, computed as the sum of income tax paid (txpd) over the previous five years divided by the sum of a firm's pre-tax income (pi) less special items (spi). 
TABLE 1

Panel A: Sample Selection

Sample Selection and ESOP Firms Distribution

\begin{tabular}{lr}
\hline Sample of Compustat firm-years (1999-2007) matched with ESOP by Employer Identification Number & Firm-Years \\
\cline { 2 - 2 } Sample after requiring data available for SIC code and total asset & 2,847 \\
Sample after matching with firms without ESOP by year, 2-digit SIC code and total asset & 2,823 \\
Sample for Table 3 after requiring data available for control variables & 5,646 \\
Sample for Table 4 after requiring data available for Fog index and control variables & 5,041 \\
\hline
\end{tabular}

\section{Table 1 Panel B ESOP Firms Distribution by Fiscal Years}

\begin{tabular}{ccc}
\hline Fiscal Year & Freq. & Percent \\
\hline 1999 & 317 & 11.23 \\
2000 & 309 & 10.95 \\
2001 & 355 & 12.58 \\
2002 & 351 & 12.43 \\
2003 & 341 & 12.08 \\
2004 & 321 & 11.37 \\
2005 & 308 & 10.91 \\
2006 & 297 & 10.52 \\
2007 & 224 & 7.93 \\
\hline Total & 2,823 & 100
\end{tabular}

$\overline{\text { (Table } 1 \text { continued on next page) }}$ 
TABLE 1

Sample Selection and ESOP Firms Distribution (continued)

Panel C: ESOP Firms Distribution by Industries (2-Digit SIC)

\begin{tabular}{|c|c|c|c|c|c|}
\hline Industry & Freq. & Percent & Industry & Freq. & Percent \\
\hline Agricultural Production - Crops & 13 & 0.46 & Industrial Machinery \& Equipment & 133 & 4.71 \\
\hline Agricultural Production - Livestock & 7 & 0.25 & Instruments \& Related Products & 117 & 4.14 \\
\hline Agricultural Services & 8 & 0.28 & Leather \& Leather Products & 26 & 0.92 \\
\hline Amusement \& Recreation Services & 39 & 1.38 & Lumber \& Wood Products & 15 & 0.53 \\
\hline Apparel \& Accessory Stores & 19 & 0.67 & Misc. Manuf. Industries & 22 & 0.78 \\
\hline Apparel \& Other Textile Products & 22 & 0.78 & Miscellaneous Repair Services & 1 & 0.04 \\
\hline Auto Repair, Services, \& Parking & 8 & 0.28 & Miscellaneous Retail & 25 & 0.89 \\
\hline Automative Dealers \& Service Stations & 7 & 0.25 & Motion Pictures & 1 & 0.04 \\
\hline Building Materials\& Gardening Supplies & 12 & 0.43 & Non classifiable Establishments & 15 & 0.53 \\
\hline Business Services & 169 & 5.99 & Oil \& Gas Extraction & 56 & 1.98 \\
\hline Chemical \& Allied Products & 297 & 10.52 & Paper \& Allied Products & 57 & 2.02 \\
\hline Coal Mining & 7 & 0.25 & Personal Services & 7 & 0.25 \\
\hline Communications & 75 & 2.66 & Petroleum \& Coal Products & 34 & 1.2 \\
\hline Eating \& Drinking Places & 37 & 1.31 & Primary Metal Industries & 64 & 2.27 \\
\hline Educational Services & 9 & 0.32 & Printing \& Publishing & 54 & 1.91 \\
\hline Electric, Gas, \& Sanitary Services & 495 & 17.53 & Railroad Transportation & 14 & 0.5 \\
\hline Electronic \& Other Electric Equipment & 158 & 5.6 & Rubber \& Miscellaneous Plastics Product & 30 & 1.06 \\
\hline Engineering \& Management Services & 48 & 1.7 & Social Services & 1 & 0.04 \\
\hline Fabricated Metal Products & 89 & 3.15 & Special Trade Contractors & 4 & 0.14 \\
\hline Food \& Kindred Products & 124 & 4.39 & Stone, Clay, \& Glass Products & 4 & 0.14 \\
\hline Food Stores & 42 & 1.49 & Textile Mill Products & 21 & 0.74 \\
\hline Furniture \& Fixtures & 53 & 1.88 & Transportation Equipment & 54 & 1.91 \\
\hline Furniture \& Homefurnishings Stores & 32 & 1.13 & Transportation Services & 9 & 0.32 \\
\hline General Building Contractors & 32 & 1.13 & Transportation by Air & 30 & 1.06 \\
\hline General Merchandise Stores & 39 & 1.38 & Trucking \& Warehousing & 10 & 0.35 \\
\hline Health Services & 15 & 0.53 & Wholesale Trade- Durable Goods & 87 & 3.08 \\
\hline Heavy Construction, Except Building & 11 & 0.39 & Wholesale Trade- Nondurable Goods & 60 & 2.13 \\
\hline Hotels \& Other Lodging Places & 5 & 0.18 & Total & 2,823 & 100 \\
\hline
\end{tabular}


TABLE 2

Descriptive Statistics and Correlation Matrix

Panel A: Descriptive Statistics of ESOP Firms

\begin{tabular}{|c|c|c|c|c|c|c|}
\hline Variable & $\mathrm{N}$ & Mean & STD & $\mathrm{P} 25$ & $\mathrm{P} 50$ & $\mathrm{P} 75$ \\
\hline UNIONR & 2,803 & 14.348 & 12.203 & 4.2 & 10.4 & 23.8 \\
\hline$M F$ & 2,823 & 0.532 & 0.499 & 0 & 1 & 1 \\
\hline$N M F$ & 2,823 & 3.031 & 4.075 & 0 & 1 & 5 \\
\hline$N G M F$ & 2,823 & 1.506 & 2.386 & 0 & 0 & 2 \\
\hline$N B M F$ & 2,823 & 1.464 & 2.232 & 0 & 0 & 2 \\
\hline$M F S$ & 2,823 & 6.563 & 8.953 & 0 & 2 & 11 \\
\hline$C C$ & 2,823 & 0.61 & 0.488 & 0 & 1 & 1 \\
\hline NCONFC & 2,823 & 2.972 & 3.015 & 0 & 4 & 5 \\
\hline FOGINV & 2,383 & -19.789 & 1.648 & -20.457 & -19.521 & -18.704 \\
\hline LENGTHINV & 2,383 & -10.524 & 0.677 & -10.965 & -10.506 & -10.065 \\
\hline SIZE & 2,823 & 7.189 & 2.15 & 5.725 & 7.400 & 8.721 \\
\hline$L E V$ & 2,823 & 0.354 & 0.262 & 0.148 & 0.353 & 0.512 \\
\hline GROWTH & 2,794 & 0.092 & 0.238 & -0.011 & 0.064 & 0.154 \\
\hline$R O A$ & 2,808 & 0.042 & 0.093 & 0.018 & 0.046 & 0.085 \\
\hline EARNVOL & 2,686 & 0.053 & 0.093 & 0.016 & 0.028 & 0.053 \\
\hline LIT & 2,823 & 0.205 & 0.404 & 0 & 0 & 0 \\
\hline$S E O$ & 2,823 & 0.029 & 0.169 & 0 & 0 & 0 \\
\hline$M A$ & 2,823 & 0.482 & 0.5 & 0 & 0 & 1 \\
\hline$A G E$ & 2,823 & 32.813 & 16.726 & 17 & 35 & 49 \\
\hline$S I$ & 2,823 & -0.008 & 0.03 & -0.008 & 0 & 0 \\
\hline NBSEG & 2,823 & 2.627 & 1.71 & 1 & 2 & 4 \\
\hline NGSEG & 2,823 & 2.188 & 1.738 & 1 & 1 & 3 \\
\hline$D L W$ & 2,823 & 0.008 & 0.088 & 0 & 0 & 0 \\
\hline ANALYFOL & 2,823 & 8.708 & 8.785 & 1 & 6 & 14 \\
\hline \multicolumn{7}{|c|}{ Panel B: Descriptive Statistics of non-ESOP Firms } \\
\hline Variable & $\mathrm{N}$ & Mean & STD & $\mathrm{P} 25$ & $\mathrm{P} 50$ & $\mathrm{P} 75$ \\
\hline$\overline{U N I O N R}$ & 2,808 & 13.685 & 12.228 & 3.4 & 9.1 & 23.3 \\
\hline$M F$ & 2,823 & 0.433 & 0.496 & 0 & 0 & 1 \\
\hline$N M F$ & 2,823 & 2.133 & 3.358 & 0 & 0 & 4 \\
\hline$N G M F$ & 2,823 & 1.029 & 1.960 & 0 & 0 & 1 \\
\hline$N B M F$ & 2,823 & 1.022 & 1.788 & 0 & 0 & 2 \\
\hline$M F S$ & 2,823 & 4.610 & 7.312 & 0 & 0 & 8 \\
\hline$C C$ & 2,823 & 0.507 & 0.500 & 0 & 1 & 1 \\
\hline NCONFC & 2,823 & 2.562 & 3.145 & 0 & 1 & 5 \\
\hline FOGINV & 2,194 & -19.976 & 1.760 & -20.728 & -19.676 & -18.848 \\
\hline LENGTHINV & 2,194 & -10.694 & 0.744 & -11.147 & -10.658 & -10.223 \\
\hline SIZE & 2,823 & 7.143 & 2.141 & 5.738 & 7.360 & 8.647 \\
\hline$L E V$ & 2,823 & 0.402 & 0.361 & 0.115 & 0.379 & 0.565 \\
\hline GROWTH & 2,736 & 0.347 & 1.583 & -0.008 & 0.079 & 0.207 \\
\hline$R O A$ & 2,754 & 0.018 & 0.207 & -0.003 & 0.035 & 0.077 \\
\hline EARNVOL & 2,411 & 0.168 & 0.709 & 0.017 & 0.036 & 0.078 \\
\hline$L I T$ & 2,823 & 0.246 & 0.431 & 0 & 0 & 0 \\
\hline$S E O$ & 2,823 & 0.032 & 0.177 & 0 & 0 & 0 \\
\hline$M A$ & 2,823 & 0.402 & 0.490 & 0 & 0 & 1 \\
\hline$A G E$ & 2,823 & 23.195 & 17.312 & 8 & 17 & 38 \\
\hline$S I$ & 2,823 & -0.012 & 0.042 & -0.011 & 0 & 0 \\
\hline NBSEG & 2,823 & 2.176 & 1.595 & 1 & 1 & 3 \\
\hline NGSEG & 2,823 & 2.258 & 1.867 & 1 & 1 & 3 \\
\hline$D L W$ & 2,823 & 0.006 & 0.080 & 0 & 0 & 0 \\
\hline ANALYFOL & 2,823 & 7.863 & 9.526 & 0 & 4 & 13 \\
\hline
\end{tabular}

Variable definitions are provided in the Appendix. (Table 2 continued on next page) 
TABLE 2

Descriptive Statistics and Correlation Matrix (continued)

Panel C: Pearson Correlation Matrix

\begin{tabular}{|c|c|c|c|c|c|c|c|c|c|c|c|}
\hline \multirow[b]{2}{*}{ UNIONR } & \multirow{2}{*}{$\begin{array}{c}E S O P \\
0.0271\end{array}$} & \multirow[t]{2}{*}{$U N I O N R$} & \multirow[t]{2}{*}{$M F$} & \multicolumn{4}{|c|}{ LOGNMFLOGNGMFLOGNBMFLOGMFS } & \multirow[t]{2}{*}{$C C$} & \multicolumn{3}{|c|}{ LOGNCONFC FOGINV LENGTHINV } \\
\hline & & & & & & & & & & & \\
\hline$M F$ & $0.0996 *$ & $-0.0856 *$ & & & & & & & & & \\
\hline$L O G N M F$ & $0.1164 *$ & $-0.0850 *$ & $0.8892 *$ & & & & & & & & \\
\hline LOGNGMF & $0.1120 *$ & $-0.0752 *$ & $0.7202 *$ & $0.8781 *$ & & & & & & & \\
\hline$L O G N B M F$ & $0.1053 *$ & $-0.0813^{*}$ & $0.7601 *$ & $0.8812 *$ & $0.6396 *$ & & & & & & \\
\hline$L O G M F S$ & $0.1149 *$ & $-0.0850 *$ & $0.9130 *$ & $0.9928 *$ & $0.8654 *$ & $0.8690 *$ & & & & & \\
\hline$C C$ & $0.1042 *$ & $-0.1527^{*}$ & $0.4802 *$ & $0.4915 *$ & $0.4532 *$ & $0.4428 *$ & $0.4977 *$ & & & & \\
\hline LOGNCONFC & C0.0898* & $-0.1651 *$ & $0.4881 *$ & $0.5281 *$ & $0.4963 *$ & $0.4773 *$ & $0.5298 *$ & $0.9383 *$ & & & \\
\hline FOGINV & $0.0547 *$ & $-0.0880^{*}$ & -0.0019 & -0.0100 & -0.0034 & -0.0047 & -0.0096 & -0.0039 & -0.0191 & & \\
\hline LENGTHINV & $0.1189 *$ & $-0.2068 *$ & $-0.0703 *$ & $-0.0920 *$ & $-0.0761 *$ & $-0.0738 *$ & $-0.0903^{*}$ & $-0.1121 *$ & $-0.1537 *$ & $0.4510 *$ & \\
\hline DSCORE & $0.1215^{*}$ & $-0.1752 *$ & $0.8931 *$ & $0.9192 *$ & $0.8150 *$ & $0.8161 *$ & $0.9265 *$ & $0.6971 *$ & $0.7142 *$ & $0.1520 *$ & $0.0615 *$ \\
\hline
\end{tabular}

*Denotes significance at the $1 \%$ level (using a two-tailed test). 


\section{TABLE 3}

\section{The Impact of ESOP and Unionization Rate on Disclosure}

Panel A: The Impact of ESOP and Unionization Rate on Disclosure

\begin{tabular}{|c|c|c|c|c|c|c|c|}
\hline & (1) & (2) & (3) & (4) & (5) & (6) & (7) \\
\hline & $M F$ & LOGNMF & LOGNGMF & FOOGNBMI & FLOGMFS & $C C$ & LOGNCONFC \\
\hline \multirow[t]{2}{*}{ ESOP } & $0.135^{*}$ & $0.107 * *$ & $0.074 * *$ & $0.073 * *$ & $0.140 * *$ & $0.225 * * *$ & $0.094 * * *$ \\
\hline & $(1.92)$ & $(2.42)$ & $(2.25)$ & $(2.31)$ & $(2.35)$ & (2.89) & $(2.85)$ \\
\hline \multirow[t]{2}{*}{ UNIONR } & $-0.007 * *$ & $-0.006 * *$ & $-0.005 * * *$ & $-0.003 * *$ & $-0.007 * *$ & $-0.012 * * *$ & $-0.006 * * *$ \\
\hline & $(2.06)$ & $(2.56)$ & $(2.92)$ & $(2.02)$ & $(2.46)$ & $(3.25)$ & $(3.41)$ \\
\hline \multirow[t]{2}{*}{$S I Z E$} & $0.068 * * *$ & $0.059 * * *$ & $0.042 * * *$ & $0.037 * * *$ & $0.078 * * *$ & 0.018 & 0.021 \\
\hline & $(2.87)$ & $(4.31)$ & $(4.30)$ & $(3.87)$ & $(4.21)$ & $(0.63)$ & $(1.59)$ \\
\hline \multirow[t]{2}{*}{$L I T$} & $0.184 *$ & $0.162 * *$ & $0.097 *$ & $0.142 * * *$ & $0.209 * *$ & 0.101 & 0.045 \\
\hline & $(1.91)$ & $(2.44)$ & $(1.95)$ & $(3.00)$ & $(2.39)$ & $(0.84)$ & $(0.89)$ \\
\hline \multirow[t]{2}{*}{$L E V$} & $-0.217 * *$ & $-0.101 *$ & -0.069 & -0.057 & $-0.134 *$ & -0.131 & -0.045 \\
\hline & $(2.11)$ & $(1.77)$ & (1.64) & $(1.46)$ & $(1.72)$ & (1.18) & $(0.92)$ \\
\hline \multirow[t]{2}{*}{ GROWTH } & -0.065 & -0.019 & 0.000 & $-0.025 * *$ & -0.022 & 0.005 & -0.004 \\
\hline & $(1.50)$ & (1.19) & $(0.03)$ & $(2.32)$ & $(0.98)$ & $(0.15)$ & $(0.24)$ \\
\hline \multirow[t]{2}{*}{$R O A$} & $1.152 * * *$ & $0.708 * * *$ & $0.563 * * *$ & $0.432 * * *$ & $0.983 * * *$ & $0.585 * *$ & $0.263 * *$ \\
\hline & $(4.60)$ & $(5.89)$ & $(6.12)$ & $(5.08)$ & $(6.03)$ & $(2.51)$ & $(2.44)$ \\
\hline \multirow[t]{2}{*}{ SEO } & $0.432 * * *$ & $0.178 * *$ & $0.151^{* *}$ & $0.104 *$ & $0.238^{* *}$ & 0.235 & $0.169 * * *$ \\
\hline & $(3.02)$ & $(2.36)$ & $(2.56)$ & $(1.73)$ & $(2.37)$ & $(1.46)$ & $(2.97)$ \\
\hline \multirow[t]{2}{*}{$M A$} & $0.341 * * *$ & $0.232 * * *$ & $0.158 * * *$ & $0.160 * * *$ & $0.316^{* * *}$ & $0.357 * * *$ & $0.172 * * *$ \\
\hline & $(7.26)$ & (7.43) & $(6.19)$ & $(6.81)$ & $(7.60)$ & $(5.89)$ & $(6.68)$ \\
\hline \multirow[t]{2}{*}{ EARNVOL } & -0.060 & -0.004 & -0.009 & -0.009 & -0.013 & -0.074 & $-0.042 *$ \\
\hline & $(1.15)$ & $(0.14)$ & $(0.44)$ & $(0.55)$ & $(0.37)$ & $(1.25)$ & (1.65) \\
\hline \multirow[t]{2}{*}{$A G E$} & -0.000 & 0.002 & $0.002 * *$ & 0.001 & 0.002 & $-0.007 * *$ & $-0.003 * * *$ \\
\hline & $(0.05)$ & $(1.21)$ & $(2.06)$ & $(1.24)$ & $(0.91)$ & $(2.42)$ & (2.64) \\
\hline \multirow[t]{2}{*}{$S I$} & $-2.369 * * *$ & $-1.257 * * *$ & $-0.532 *$ & $-1.037 * * *$ & $-1.670 * * *$ & -0.145 & -0.091 \\
\hline & $(3.46)$ & $(3.48)$ & (1.86) & $(3.70)$ & $(3.43)$ & $(0.19)$ & $(0.26)$ \\
\hline \multirow[t]{2}{*}{$N B S E G$} & $0.080 * * *$ & $0.052 * * *$ & $0.038 * * *$ & $0.034 * * *$ & $0.072 * * *$ & $0.109 * * *$ & $0.048 * * *$ \\
\hline & $(3.26)$ & $(3.47)$ & $(3.41)$ & $(3.18)$ & $(3.60)$ & $(4.27)$ & $(4.60)$ \\
\hline \multirow[t]{2}{*}{$N G S E G$} & -0.022 & $-0.029 * *$ & $-0.024 * *$ & $-0.021 * *$ & $-0.036^{*}$ & $0.072 * * *$ & $0.028 * * *$ \\
\hline & $(0.94)$ & $(2.02)$ & $(2.29)$ & $(2.00)$ & $(1.85)$ & $(2.79)$ & $(2.82)$ \\
\hline \multirow[t]{2}{*}{$D L W$} & -0.465 & -0.258 & $-0.204 *$ & -0.102 & -0.355 & $-0.820 *$ & $-0.321 *$ \\
\hline & $(1.45)$ & $(1.33)$ & (1.88) & $(0.59)$ & $(1.37)$ & $(1.86)$ & (1.93) \\
\hline \multirow[t]{2}{*}{ ANALYFOL } & $0.037 * * *$ & $0.023 * * *$ & $0.014 * * *$ & $0.017 * * *$ & $0.032 * * *$ & $0.079 * * *$ & $0.035 * * *$ \\
\hline & $(5.90)$ & $(6.27)$ & $(5.28)$ & (6.63) & $(6.31)$ & $(10.58)$ & (13.83) \\
\hline \multirow[t]{2}{*}{ HERFIN } & $0.784 * * *$ & $0.445^{* * *}$ & $0.288 * *$ & $0.328 * * *$ & $0.621 * * *$ & -0.371 & -0.131 \\
\hline & $(3.29)$ & $(2.91)$ & $(2.51)$ & $(3.06)$ & $(3.09)$ & $(1.38)$ & (1.06) \\
\hline \multirow[t]{2}{*}{ IROA } & 0.233 & 0.254 & 0.167 & 0.035 & 0.322 & 0.443 & -0.165 \\
\hline & $(0.54)$ & $(0.89)$ & $(0.72)$ & $(0.17)$ & $(0.86)$ & $(0.92)$ & $(0.84)$ \\
\hline \multirow[t]{2}{*}{ Constant } & $-1.257 * * *$ & -0.084 & $-0.115^{*}$ & -0.090 & -0.080 & -0.123 & $0.446 * * *$ \\
\hline & $(7.59)$ & $(0.96)$ & $(1.75)$ & $(1.46)$ & $(0.69)$ & $(0.65)$ & $(5.88)$ \\
\hline Year FE & YES & YES & YES & YES & YES & YES & YES \\
\hline Observations & 5,041 & 5,041 & 5,041 & 5,041 & 5,041 & 5,041 & 5,041 \\
\hline Adj. or Pseudo R-squared & 0.170 & 0.262 & 0.222 & 0.209 & 0.263 & 0.359 & 0.490 \\
\hline
\end{tabular}

T-statistics clustered by firm are presented in the parentheses. * significant at 10\%; ** significant at 5\%; *** significant at $1 \%$ (two-sided test). Variable definitions are provided in the Appendix. (Table 3 continued on next page) 
TABLE 3

The Impact of ESOP and Unionization Rate on Disclosure (continued)

Panel B: The Impact of ESOP Interacted with Unionization Rate on Disclosure

\begin{tabular}{|c|c|c|c|c|c|c|c|}
\hline & $\begin{array}{l}(1) \\
M F\end{array}$ & $\begin{array}{l}\text { (2) } \\
\text { LOGNMF }\end{array}$ & $\begin{array}{l}(3) \\
L O G N G M F\end{array}$ & LOGNBMF & $\begin{array}{l}5) \\
L O G M F S\end{array}$ & $\begin{array}{l}\text { (6) } \\
C C\end{array}$ & $\begin{array}{l}\text { (7) } \\
\text { LOGNCONFC }\end{array}$ \\
\hline ESOP & $\begin{array}{l}-0.092 \\
(0.94)\end{array}$ & $\begin{array}{l}-0.011 \\
(0.17)\end{array}$ & $\begin{array}{l}0.009 \\
(0.19)\end{array}$ & $\begin{array}{l}-0.015 \\
(0.33)\end{array}$ & $\begin{array}{l}-0.023 \\
(0.27)\end{array}$ & $\begin{array}{l}0.011 \\
(0.09)\end{array}$ & $\begin{array}{l}-0.018 \\
(0.37)\end{array}$ \\
\hline UNIONR & $\begin{array}{l}-0.016^{* * * *} \\
(3.66)\end{array}$ & $\begin{array}{l}-0.010 * * * \\
(3.88)\end{array}$ & $\begin{array}{l}-0.007 * * * \\
(3.69)\end{array}$ & $\begin{array}{l}-0.007 * * * \\
(3.44)\end{array}$ & $\begin{array}{l}-0.014 * * * \\
(3.85)\end{array}$ & $\begin{array}{l}-0.020 * * * \\
(4.04)\end{array}$ & $\begin{array}{l}-0.010 * * * \\
(4.67)\end{array}$ \\
\hline$E S O P \times U N I O N R$ & $\begin{array}{l}0.016^{* * * *} \\
(3.14)\end{array}$ & $\begin{array}{l}0.008 * * * \\
(2.65)\end{array}$ & $\begin{array}{l}0.005^{*} \\
(1.95)\end{array}$ & $\begin{array}{l}0.006^{* * * *} \\
(2.72)\end{array}$ & $\begin{array}{l}0.012 * * * \\
(2.75)\end{array}$ & $\begin{array}{l}0.015 * * \\
(2.46)\end{array}$ & $\begin{array}{l}0.008 * * * \\
(3.05)\end{array}$ \\
\hline SIZE & $\begin{array}{l}0.073 * * * \\
(3.05)\end{array}$ & $\begin{array}{l}0.062 * * * \\
(4.48)\end{array}$ & $\begin{array}{l}0.043 * * * \\
(4.43)\end{array}$ & $\begin{array}{l}0.039 * * * \\
(4.07)\end{array}$ & $\begin{array}{l}0.082 * * * \\
(4.39)\end{array}$ & $\begin{array}{l}0.022 \\
(0.75)\end{array}$ & $\begin{array}{l}0.024 * \\
(1.80)\end{array}$ \\
\hline$L I T$ & $\begin{array}{l}0.182^{*} \\
(1.88)\end{array}$ & $\begin{array}{l}0.162 * * \\
(2.44)\end{array}$ & $\begin{array}{l}0.097^{*} \\
(1.94)\end{array}$ & $\begin{array}{l}0.142 * * * \\
(2.99)\end{array}$ & $\begin{array}{l}0.209 * * \\
(2.38)\end{array}$ & $\begin{array}{l}0.100 \\
(0.83)\end{array}$ & $\begin{array}{l}0.045 \\
(0.89)\end{array}$ \\
\hline$L E V$ & $\begin{array}{l}-0.216^{* *} \\
(2.10)\end{array}$ & $\begin{array}{l}-0.102 * \\
(1.78)\end{array}$ & $\begin{array}{l}-0.070 \\
(1.64)\end{array}$ & $\begin{array}{l}-0.058 \\
(1.47)\end{array}$ & $\begin{array}{l}-0.135^{*} \\
(1.73)\end{array}$ & $\begin{array}{l}-0.130 \\
(1.17)\end{array}$ & $\begin{array}{l}-0.046 \\
(0.93)\end{array}$ \\
\hline GROWTH & $\begin{array}{l}-0.071^{*} \\
(1.65)\end{array}$ & $\begin{array}{l}-0.023 \\
(1.41)\end{array}$ & $\begin{array}{l}-0.002 \\
(0.12)\end{array}$ & $\begin{array}{l}-0.028 * * \\
(2.55)\end{array}$ & $\begin{array}{l}-0.027 \\
(1.19)\end{array}$ & $\begin{array}{l}-0.000 \\
(0.01)\end{array}$ & $\begin{array}{l}-0.007 \\
(0.45)\end{array}$ \\
\hline$R O A$ & $\begin{array}{l}1.174 * * * \\
(4.69)\end{array}$ & $\begin{array}{l}0.720 \text { *** } \\
(5.97)\end{array}$ & $\begin{array}{l}0.569 * * * \\
(6.16)\end{array}$ & $\begin{array}{l}0.441 \text { *** } \\
(5.18)\end{array}$ & $\begin{array}{l}0.999 * * * \\
(6.11)\end{array}$ & $\begin{array}{l}0.610 \text { *** } \\
(2.60)\end{array}$ & $\begin{array}{l}0.275 * * \\
(2.54)\end{array}$ \\
\hline SEO & $\begin{array}{l}0.427 * * * \\
(2.91)\end{array}$ & $\begin{array}{l}0.173 * * \\
(2.27)\end{array}$ & $\begin{array}{l}0.148 * * \\
(2.51)\end{array}$ & $\begin{array}{l}0.100 * \\
(1.66)\end{array}$ & $\begin{array}{l}0.231 * * \\
(2.28)\end{array}$ & $\begin{array}{l}0.236 \\
(1.47)\end{array}$ & $\begin{array}{l}0.164 * * * \\
(2.90)\end{array}$ \\
\hline$M A$ & $\begin{array}{l}0.343 * * * \\
(7.35)\end{array}$ & $\begin{array}{l}0.231 * * * \\
(7.43)\end{array}$ & $\begin{array}{l}0.158 * * * \\
(6.18)\end{array}$ & $\begin{array}{l}0.160 * * * \\
(6.82)\end{array}$ & $\begin{array}{l}0.315 * * * \\
(7.60)\end{array}$ & $\begin{array}{l}0.359 * * * \\
(5.92)\end{array}$ & $\begin{array}{l}0.171 * * * \\
(6.67)\end{array}$ \\
\hline EARNVOL & $\begin{array}{l}-0.059 \\
(1.12)\end{array}$ & $\begin{array}{l}-0.003 \\
(0.10)\end{array}$ & $\begin{array}{l}-0.008 \\
(0.41)\end{array}$ & $\begin{array}{l}-0.009 \\
(0.50)\end{array}$ & $\begin{array}{l}-0.012 \\
(0.33)\end{array}$ & $\begin{array}{l}-0.076 \\
(1.27)\end{array}$ & $\begin{array}{l}-0.041 \\
(1.61)\end{array}$ \\
\hline$A G E$ & $\begin{array}{l}-0.000 \\
(0.09)\end{array}$ & $\begin{array}{l}0.002 \\
(1.17)\end{array}$ & $\begin{array}{l}0.002 * * \\
(2.03)\end{array}$ & $\begin{array}{l}0.001 \\
(1.20)\end{array}$ & $\begin{array}{l}0.002 \\
(0.87)\end{array}$ & $\begin{array}{l}-0.007 * * \\
(2.47)\end{array}$ & $\begin{array}{l}-0.003 * * * \\
(2.69)\end{array}$ \\
\hline$S I$ & $\begin{array}{l}-2.310 * * * \\
(3.35)\end{array}$ & $\begin{array}{l}-1.224 * * * \\
(3.37)\end{array}$ & $\begin{array}{l}-0.514^{*} \\
(1.79)\end{array}$ & $\begin{array}{l}-1.013 * * * \\
(3.61)\end{array}$ & $\begin{array}{l}-1.625 * * * \\
(3.32)\end{array}$ & $\begin{array}{l}-0.079 \\
(0.10)\end{array}$ & $\begin{array}{l}-0.060 \\
(0.17)\end{array}$ \\
\hline$N B S E G$ & $\begin{array}{l}0.081 * * * \\
(3.35)\end{array}$ & $\begin{array}{l}0.052 * * * \\
(3.50)\end{array}$ & $\begin{array}{l}0.038 * * * \\
(3.44)\end{array}$ & $\begin{array}{l}0.034 * * * \\
(3.22)\end{array}$ & $\begin{array}{l}0.072 * * * \\
(3.63)\end{array}$ & $\begin{array}{l}0.110 * * * \\
(4.28)\end{array}$ & $\begin{array}{l}0.048 * * * \\
(4.64)\end{array}$ \\
\hline$N G S E G$ & $\begin{array}{l}-0.023 \\
(0.99)\end{array}$ & $\begin{array}{l}-0.030 * * \\
(2.06)\end{array}$ & $\begin{array}{l}-0.024 * * \\
(2.32)\end{array}$ & $\begin{array}{l}-0.021 * * \\
(2.05)\end{array}$ & $\begin{array}{l}-0.037 * \\
(1.89)\end{array}$ & $\begin{array}{l}0.072 * * * \\
(2.73)\end{array}$ & $\begin{array}{l}0.027 * * * \\
(2.75)\end{array}$ \\
\hline$D L W$ & $\begin{array}{l}-0.459 \\
(1.39)\end{array}$ & $\begin{array}{l}-0.255 \\
(1.28)\end{array}$ & $\begin{array}{l}-0.202^{*} \\
(1.82)\end{array}$ & $\begin{array}{l}-0.099 \\
(0.56)\end{array}$ & $\begin{array}{l}-0.351 \\
(1.32)\end{array}$ & $\begin{array}{l}-0.826^{*} \\
(1.83)\end{array}$ & $\begin{array}{l}-0.318^{*} \\
(1.81)\end{array}$ \\
\hline ANALYFOL & $\begin{array}{l}0.035 * * * \\
(5.57)\end{array}$ & $\begin{array}{l}0.022 * * * \\
(5.89)\end{array}$ & $\begin{array}{l}0.014 * * * \\
(4.99)\end{array}$ & $\begin{array}{l}0.016^{* * * *} \\
(6.23)\end{array}$ & $\begin{array}{l}0.030 * * * \\
(5.93)\end{array}$ & $\begin{array}{l}0.078 * * * \\
(10.27)\end{array}$ & $\begin{array}{l}0.034 * * * \\
(13.02)\end{array}$ \\
\hline HERFIN & $\begin{array}{l}0.812 * * * \\
(3.44)\end{array}$ & $\begin{array}{l}0.456 * * * \\
(3.02)\end{array}$ & $\begin{array}{l}0.294 * * * \\
(2.59)\end{array}$ & $\begin{array}{l}0.337 * * * \\
(3.17)\end{array}$ & $\begin{array}{l}0.637 * * * \\
(3.21)\end{array}$ & $\begin{array}{l}-0.350 \\
(1.30)\end{array}$ & $\begin{array}{l}-0.120 \\
(0.97)\end{array}$ \\
\hline IROA & $\begin{array}{l}0.240 \\
(0.55)\end{array}$ & $\begin{array}{l}0.257 \\
(0.90)\end{array}$ & $\begin{array}{l}0.169 \\
(0.73)\end{array}$ & $\begin{array}{l}0.037 \\
(0.18)\end{array}$ & $\begin{array}{l}0.326 \\
(0.87)\end{array}$ & $\begin{array}{l}0.437 \\
(0.91)\end{array}$ & $\begin{array}{l}-0.162 \\
(0.83)\end{array}$ \\
\hline Constant & $\begin{array}{l}-1.164 * * * \\
(6.94)\end{array}$ & $\begin{array}{l}-0.035 \\
(0.39)\end{array}$ & $\begin{array}{l}-0.088 \\
(1.30)\end{array}$ & $\begin{array}{l}-0.053 \\
(0.84)\end{array}$ & $\begin{array}{l}-0.012 \\
(0.10)\end{array}$ & $\begin{array}{l}-0.026 \\
(0.14)\end{array}$ & $\begin{array}{l}0.492 * * * \\
(6.55)\end{array}$ \\
\hline $\begin{array}{l}\text { Year FE } \\
\text { Observations }\end{array}$ & $\begin{array}{l}\text { YES } \\
5,041\end{array}$ & $\begin{array}{l}\text { YES } \\
5,041\end{array}$ & $\begin{array}{l}\text { YES } \\
5,041\end{array}$ & $\begin{array}{l}\text { YES } \\
5,041\end{array}$ & $\begin{array}{c}\text { YES } \\
5,041\end{array}$ & $\begin{array}{r}\text { YES } \\
5,041\end{array}$ & $\begin{array}{l}\text { YES } \\
5,041\end{array}$ \\
\hline Adj. or Pseudo R-so & 0.174 & 0.265 & 0.224 & 0.211 & 0.266 & 0.362 & 0.493 \\
\hline
\end{tabular}


TABLE 4

The Impact of ESOP on Readability

\begin{tabular}{|c|c|c|c|c|}
\hline & $\begin{array}{l}(1) \\
\text { FOGINV }\end{array}$ & $\begin{array}{l}\text { (2) } \\
\text { LENGTHINV }\end{array}$ & $\begin{array}{l}(3) \\
\text { FOGINV }\end{array}$ & $\begin{array}{l}\text { (4) } \\
\text { LENGTHINV }\end{array}$ \\
\hline ESOP & $\begin{array}{l}0.230 * * * \\
(2.98)\end{array}$ & $\begin{array}{l}0.142 * * * \\
(4.50)\end{array}$ & $\begin{array}{l}0.204 * \\
(1.80)\end{array}$ & $\begin{array}{l}0.091 * * \\
(2.06)\end{array}$ \\
\hline UNIONR & $\begin{array}{l}-0.008 * * \\
(2.08)\end{array}$ & $\begin{array}{l}-0.009 * * * \\
(5.92)\end{array}$ & $\begin{array}{l}-0.009^{*} \\
(1.69)\end{array}$ & $\begin{array}{l}-0.011 \text { *** } \\
(4.94)\end{array}$ \\
\hline$E S O P \times U N I O N R$ & & & $\begin{array}{l}0.002 \\
(0.29)\end{array}$ & $\begin{array}{l}0.004 \\
(1.35)\end{array}$ \\
\hline$S I Z E$ & $\begin{array}{l}-0.079 * * * \\
(3.33)\end{array}$ & $\begin{array}{l}-0.125^{* * *} \\
(12.85)\end{array}$ & $\begin{array}{l}-0.078 * * * \\
(3.32)\end{array}$ & $\begin{array}{l}-0.125 * * * \\
(12.89)\end{array}$ \\
\hline GROWTH & $\begin{array}{l}-0.012 \\
(0.26)\end{array}$ & $\begin{array}{l}-0.038^{*} \\
(1.67)\end{array}$ & $\begin{array}{l}-0.013 \\
(0.27)\end{array}$ & $\begin{array}{l}-0.040^{*} \\
(1.76)\end{array}$ \\
\hline$A G E$ & $\begin{array}{l}0.000 \\
(0.03)\end{array}$ & $\begin{array}{l}0.003 * * \\
(2.35)\end{array}$ & $\begin{array}{l}0.000 \\
(0.03)\end{array}$ & $\begin{array}{l}0.003 * * \\
(2.35)\end{array}$ \\
\hline$S I$ & $\begin{array}{l}2.163 * * * \\
(2.58)\end{array}$ & $\begin{array}{l}1.831 * * * \\
(5.87)\end{array}$ & $\begin{array}{l}2.171 * * * \\
(2.60)\end{array}$ & $\begin{array}{l}1.847 * * * \\
(5.93)\end{array}$ \\
\hline EARNVOL & $\begin{array}{l}-0.047 \\
(0.67)\end{array}$ & $\begin{array}{l}-0.012 \\
(0.33)\end{array}$ & $\begin{array}{l}-0.047 \\
(0.66)\end{array}$ & $\begin{array}{l}-0.010 \\
(0.29)\end{array}$ \\
\hline NBSEG & $\begin{array}{l}-0.045^{*} \\
(1.76)\end{array}$ & $\begin{array}{l}-0.021 * * \\
(2.26)\end{array}$ & $\begin{array}{l}-0.045^{*} \\
(1.76)\end{array}$ & $\begin{array}{l}-0.021 * * \\
(2.24)\end{array}$ \\
\hline NGSEG & $\begin{array}{l}0.111 * * * \\
(5.14)\end{array}$ & $\begin{array}{l}0.004 \\
(0.50)\end{array}$ & $\begin{array}{l}0.111 * * * \\
(5.14)\end{array}$ & $\begin{array}{l}0.004 \\
(0.47)\end{array}$ \\
\hline SEO & $\begin{array}{l}-0.212 \\
(1.12)\end{array}$ & $\begin{array}{l}-0.182^{* * *} \\
(2.93)\end{array}$ & $\begin{array}{l}-0.214 \\
(1.13)\end{array}$ & $\begin{array}{l}-0.186^{* * * *} \\
(2.95)\end{array}$ \\
\hline$M A$ & $\begin{array}{l}-0.003 \\
(0.04)\end{array}$ & $\begin{array}{l}-0.060 * * \\
(2.37)\end{array}$ & $\begin{array}{l}-0.004 \\
(0.06)\end{array}$ & $\begin{array}{l}-0.062^{* *} \\
(2.43)\end{array}$ \\
\hline$D L W$ & $\begin{array}{l}-0.852^{* *} \\
(2.18)\end{array}$ & $\begin{array}{l}-0.127 \\
(0.79)\end{array}$ & $\begin{array}{l}-0.852 * * \\
(2.17)\end{array}$ & $\begin{array}{l}-0.126 \\
(0.78)\end{array}$ \\
\hline HERFIN & $\begin{array}{l}0.356 \\
(1.41)\end{array}$ & $\begin{array}{l}0.444 * * * \\
(4.87)\end{array}$ & $\begin{array}{l}0.359 \\
(1.42)\end{array}$ & $\begin{array}{l}0.450 * * * \\
(4.90)\end{array}$ \\
\hline IROA & $\begin{array}{l}0.227 \\
(0.51)\end{array}$ & $\begin{array}{l}0.686^{* * *} \\
(3.98)\end{array}$ & $\begin{array}{l}0.232 \\
(0.52)\end{array}$ & $\begin{array}{l}0.697 * * * \\
(4.05)\end{array}$ \\
\hline Constant & $\begin{array}{l}-19.501 * * * \\
(126.14)\end{array}$ & $\begin{array}{l}-9.683^{* * *} \\
(146.82)\end{array}$ & $\begin{array}{l}-19.489 * * * \\
(123.37)\end{array}$ & $\begin{array}{l}-9.658 * * * \\
(143.89)\end{array}$ \\
\hline Year FE & YES & YES & YES & YES \\
\hline Observations & 4,197 & 4,197 & 4,197 & 4,197 \\
\hline Adj. R-squared & 0.061 & 0.260 & 0.060 & 0.261 \\
\hline
\end{tabular}

T-statistics clustered by firm are presented in the parentheses. * significant at 10\%; ** significant at 5\%; *** significant at $1 \%$ (two-sided test). Variable definitions are provided in the Appendix. 
TABLE 5

The Impact of ESOP on Disclosure Score

\begin{tabular}{|c|c|c|}
\hline & $\begin{array}{l}(1) \\
\text { DSCORE }\end{array}$ & $\begin{array}{l}\text { (2) } \\
\text { DSCORE }\end{array}$ \\
\hline$E S O P$ & $\begin{array}{l}0.041 * * * \\
(3.05)\end{array}$ & $\begin{array}{l}0.001 \\
(0.05)\end{array}$ \\
\hline UNIONR & $\begin{array}{l}-0.002 * * * \\
(3.23)\end{array}$ & $\begin{array}{l}-0.004 * * * \\
(4.58)\end{array}$ \\
\hline$E S O P \times U N I O N R$ & & $\begin{array}{l}0.003 * * * \\
(2.94)\end{array}$ \\
\hline SIZE & $\begin{array}{l}0.002 \\
(0.44)\end{array}$ & $\begin{array}{l}0.004 \\
(0.71)\end{array}$ \\
\hline$L I T$ & $\begin{array}{l}0.042 * * \\
(2.26)\end{array}$ & $\begin{array}{l}0.041 * * \\
(2.22)\end{array}$ \\
\hline$L E V$ & $\begin{array}{l}-0.040 * * \\
(2.34)\end{array}$ & $\begin{array}{l}-0.041 * * \\
(2.34)\end{array}$ \\
\hline GROWTH & $\begin{array}{l}-0.008 \\
(1.16)\end{array}$ & $\begin{array}{l}-0.009 \\
(1.37)\end{array}$ \\
\hline$R O A$ & $\begin{array}{l}0.246^{* * * *} \\
(5.62)\end{array}$ & $\begin{array}{l}0.250 * * * \\
(5.68)\end{array}$ \\
\hline SEO & $\begin{array}{l}0.055 * * * \\
(2.88)\end{array}$ & $\begin{array}{l}0.053 * * * \\
(2.75)\end{array}$ \\
\hline$M A$ & $\begin{array}{l}0.070 \text { *** } \\
(7.80)\end{array}$ & $\begin{array}{l}0.070 * * * \\
(7.80)\end{array}$ \\
\hline EARNVOL & $\begin{array}{l}-0.004 \\
(0.45)\end{array}$ & $\begin{array}{l}-0.003 \\
(0.33)\end{array}$ \\
\hline$A G E$ & $\begin{array}{l}0.000 \\
(0.30)\end{array}$ & $\begin{array}{l}0.000 \\
(0.26)\end{array}$ \\
\hline$S I$ & $\begin{array}{l}-0.201 * \\
(1.67)\end{array}$ & $\begin{array}{l}-0.195 \\
(1.61)\end{array}$ \\
\hline NBSEG & $\begin{array}{l}0.016 \text { *** } \\
(3.63)\end{array}$ & $\begin{array}{l}0.016 \text { *** } \\
(3.68)\end{array}$ \\
\hline$N G S E G$ & $\begin{array}{l}-0.003 \\
(0.74)\end{array}$ & $\begin{array}{l}-0.003 \\
(0.77)\end{array}$ \\
\hline$D L W$ & $\begin{array}{l}-0.128^{*} \\
(1.86)\end{array}$ & $\begin{array}{l}-0.128^{*} \\
(1.79)\end{array}$ \\
\hline ANALYFOL & $\begin{array}{l}0.009 * * * \\
(8.22)\end{array}$ & $\begin{array}{l}0.009 * * * \\
(7.69)\end{array}$ \\
\hline HERFIN & $\begin{array}{l}0.111^{* *} \\
(2.39)\end{array}$ & $\begin{array}{l}0.115 * * \\
(2.53)\end{array}$ \\
\hline IROA & $\begin{array}{l}0.078 \\
(1.00)\end{array}$ & $\begin{array}{l}0.081 \\
(1.03)\end{array}$ \\
\hline Constant & $\begin{array}{l}0.034 \\
(1.16)\end{array}$ & $\begin{array}{l}0.050^{*} \\
(1.66)\end{array}$ \\
\hline Year FE & YES & YES \\
\hline Observations & 4,197 & 4,197 \\
\hline Adj. R-squared & 0.312 & 0.316 \\
\hline
\end{tabular}

T-statistics clustered by firm are presented in the parentheses. * significant at 10\%; ** significant at 5\%; *** significant at $1 \%$ (two-sided test). Variable definitions are provided in the Appendix. 
TABLE 6

Market Outcome Tests

\begin{tabular}{|c|c|c|}
\hline & $\begin{array}{l}\text { (1) } \\
\text { SPREAD }\end{array}$ & $\begin{array}{l}(2) \\
P I N\end{array}$ \\
\hline$E S O P$ & $\begin{array}{l}0.0023 \\
(1.64)\end{array}$ & $\begin{array}{l}0.0077 \\
(1.52)\end{array}$ \\
\hline UNIONR & $\begin{array}{l}0.0001^{*} \\
(1.75)\end{array}$ & $\begin{array}{l}0.0004 * * \\
(1.98)\end{array}$ \\
\hline$E S O P \times U N I O N R$ & $\begin{array}{l}-0.0002 * * * \\
(2.97)\end{array}$ & $\begin{array}{l}-0.0004 * \\
(1.78)\end{array}$ \\
\hline SIZE & $\begin{array}{l}-0.0065^{* * * *} \\
(11.76)\end{array}$ & $\begin{array}{l}-0.0177 * * * \\
(10.47)\end{array}$ \\
\hline$L I T$ & $\begin{array}{l}-0.0048 * * * \\
(4.01)\end{array}$ & $\begin{array}{l}0.0039 \\
(0.67)\end{array}$ \\
\hline$L E V$ & $\begin{array}{l}0.0066^{* * * *} \\
(3.41)\end{array}$ & $\begin{array}{l}0.0008 \\
(0.11)\end{array}$ \\
\hline GROWTH & $\begin{array}{l}-0.0009 * \\
(1.77)\end{array}$ & $\begin{array}{l}-0.0005 \\
(0.19)\end{array}$ \\
\hline$R O A$ & $\begin{array}{l}-0.0017 \\
(0.45)\end{array}$ & $\begin{array}{l}-0.0619 * * * \\
(2.61)\end{array}$ \\
\hline SEO & $\begin{array}{l}-0.0031 * * * \\
(2.91)\end{array}$ & $\begin{array}{l}0.0001 \\
(0.02)\end{array}$ \\
\hline$M A$ & $\begin{array}{l}0.0008 \\
(1.10)\end{array}$ & $\begin{array}{l}-0.0001 \\
(0.03)\end{array}$ \\
\hline EARNVOL & $\begin{array}{l}0.0003 \\
(0.29)\end{array}$ & $\begin{array}{l}0.0007 \\
(0.20)\end{array}$ \\
\hline$A G E$ & $\begin{array}{l}0.0002 * * * \\
(4.71)\end{array}$ & $\begin{array}{l}-0.0001 \\
(0.65)\end{array}$ \\
\hline ANALYFOL & $\begin{array}{l}-0.0001 \\
(0.87)\end{array}$ & $\begin{array}{l}-0.0023 * * * \\
(7.56)\end{array}$ \\
\hline$N A S D$ & $\begin{array}{l}0.0017 \\
(1.31)\end{array}$ & $\begin{array}{l}-0.0078 \\
(1.39)\end{array}$ \\
\hline PRICE & $\begin{array}{l}-0.0001 * * \\
(2.14)\end{array}$ & $\begin{array}{l}-0.0001 \\
(0.84)\end{array}$ \\
\hline$V O L$ & $\begin{array}{l}0.0172 * * * \\
(3.97)\end{array}$ & $\begin{array}{l}0.1683^{* * * *} \\
(3.45)\end{array}$ \\
\hline STDRET & $\begin{array}{l}0.0433 * * * \\
(5.52)\end{array}$ & $\begin{array}{l}0.0632 * * * \\
(2.64)\end{array}$ \\
\hline HERFIN & $\begin{array}{l}0.0001 \\
(0.04)\end{array}$ & $\begin{array}{l}0.0173 \\
(1.30)\end{array}$ \\
\hline IROA & $\begin{array}{l}0.0154 * * * \\
(2.90)\end{array}$ & $\begin{array}{l}0.0965^{* * * *} \\
(3.59)\end{array}$ \\
\hline Constant & $\begin{array}{l}0.0530^{* * * *} \\
(15.43)\end{array}$ & $\begin{array}{l}0.2997 * * * \\
(22.23)\end{array}$ \\
\hline Year FE & YES & YES \\
\hline Observations & 4,255 & 1,184 \\
\hline Adj. R-squared & 0.385 & 0.517 \\
\hline
\end{tabular}

T-statistics clustered by firm are presented in the parentheses. * significant at 10\%; ** significant at 5\%; *** significant at $1 \%$ (two-sided test). Variable definitions are provided in the Appendix. 
TABLE 7

Additional Endogeneity Tests

Panel A: Two-step Heckman Correction

SIZE

(1)

ESOP DSCORE

$L E V$

$0.158 * * * \quad 0.017 * * *$

(23.12) (6.33)

$-0.109 * * * \quad-0.048 * * *$

(3.13) (10.53)

GROWTH

$-0.209 * * *$

$-0.004 * * *$

(4.72)

(2.71)

$R O A$

$0.693 * * *$

$0.026 * * *$

(6.87) (5.02)

$M A$

$0.052 * *$

$0.045 * * *$

UNIONR

(2.05)

(10.32)

$0.009 * * *$

$-0.004 * * *$

(7.89)

(9.33)

CASHETR

$0.446 * * *$

(7.94)

ESOP

$-0.006$

(0.07)

$E S O P \times U N I O N R$

$0.003 * * *$

(2.83)

LIT

$0.039 * * *$

(4.82)

SEO

0.000

$(0.03)$

EARNVOL

$-0.000$

$(0.01)$

AGE

$-0.000^{*}$

(1.77)

SI

$0.033^{* * *}$

(3.11)

NBSEG

$0.012 * * *$

(4.99)

NGSEG

$0.007 * * *$

(3.30)

DLW

$-0.115^{* * * *}$

(2.91)

ANALYFOL

$0.013 * * *$

(20.11)

$0.090 * * *$

HI

(4.05)

IROA

$0.204 * * *$

(6.38)

$I M R$

0.014

$(0.36)$

Constant

$-2.512 * * *$

$-0.029 * *$

Year FE

(55.94)

(2.44)

Observations

No

Yes

23,466

23,466

Adj. or Pseudo R-squared

0.090

0.333

T-statistics clustered by firm are presented in the parentheses. * significant at 10\%; ** significant at 5\%; *** significant at $1 \%$ (two-sided test). Variable definitions are provided in the Appendix. (Table 8 continued on next page) 
TABLE 7

Additional Endogeneity Tests (continued)

Panel B: The Impact of ESOP Initiation on Disclosure Score

\begin{tabular}{|c|c|}
\hline & DDSCORE \\
\hline \multirow[t]{2}{*}{ INIT } & $0.053 * * *$ \\
\hline & $(2.87)$ \\
\hline \multirow[t]{2}{*}{ DSIZE } & 0.093 \\
\hline & $(1.41)$ \\
\hline \multirow[t]{2}{*}{$D L E V$} & 0.043 \\
\hline & $(1.05)$ \\
\hline \multirow[t]{2}{*}{ DGROWTH } & -0.016 \\
\hline & $(0.43)$ \\
\hline \multirow[t]{2}{*}{$D R O A$} & 0.366 \\
\hline & $(1.51)$ \\
\hline \multirow[t]{2}{*}{$D S E O$} & 0.053 \\
\hline & $(0.84)$ \\
\hline \multirow[t]{2}{*}{$D M A$} & -0.028 \\
\hline & $(0.96)$ \\
\hline \multirow[t]{2}{*}{ DEARNVOL } & -0.068 \\
\hline & $(1.02)$ \\
\hline \multirow[t]{2}{*}{$D S I$} & -0.568 \\
\hline & $(1.57)$ \\
\hline \multirow[t]{2}{*}{$D N B S E G$} & 0.007 \\
\hline & $(0.54)$ \\
\hline \multirow[t]{2}{*}{$D N G S E G$} & $0.028 * *$ \\
\hline & $(1.98)$ \\
\hline \multirow[t]{2}{*}{$D A N A L Y F O L$} & 0.003 \\
\hline & $(0.57)$ \\
\hline Observations & 157 \\
\hline Adj. R-squared & 0.129 \\
\hline
\end{tabular}

T-statistics clustered by firm are presented in the parentheses. * significant at 10\%; ** significant at 5\%; *** significant at $1 \%$ (two-sided test). Variable definitions are provided in the Appendix. (Table 8 continued on next page) 
TABLE 8

Additional Analyses

Panel A: The Impact of ESOP Holding Per Participant on Disclosure

\begin{tabular}{|c|c|c|}
\hline & $\begin{array}{l}(1) \\
D S C O R E\end{array}$ & $\begin{array}{l}\text { (2) } \\
\text { DSCORE }\end{array}$ \\
\hline \multirow[t]{2}{*}{ ESOPHPE } & $0.017 *$ & -0.001 \\
\hline & $(1.93)$ & $(0.05)$ \\
\hline \multirow[t]{2}{*}{ UNIONR } & -0.001 & $-0.017 * *$ \\
\hline & $(0.65)$ & $(2.03)$ \\
\hline \multirow[t]{2}{*}{ ESOPHPE $\times U N I O N R$} & & $0.001 * *$ \\
\hline & & $(1.97)$ \\
\hline \multirow[t]{2}{*}{$M B$} & 0.003 & 0.005 \\
\hline & $(0.23)$ & $(0.38)$ \\
\hline \multirow[t]{2}{*}{ SIZE } & $0.016 * *$ & $0.017 * *$ \\
\hline & (1.99) & $(2.10)$ \\
\hline \multirow[t]{2}{*}{$L I T$} & $0.038 *$ & 0.034 \\
\hline & $(1.67)$ & $(1.52)$ \\
\hline \multirow[t]{2}{*}{$L E V$} & $-0.086 * *$ & $-0.093 * *$ \\
\hline & $(2.19)$ & $(2.37)$ \\
\hline \multirow[t]{2}{*}{ GROWTH } & $0.096 *$ & $0.099 * *$ \\
\hline & $(1.95)$ & $(2.02)$ \\
\hline \multirow[t]{2}{*}{$R O A$} & 0.029 & 0.042 \\
\hline & $(0.18)$ & $(0.26)$ \\
\hline \multirow[t]{2}{*}{ SEO } & 0.021 & 0.017 \\
\hline & $(0.48)$ & $(0.40)$ \\
\hline \multirow[t]{2}{*}{$M A$} & $0.051 * * *$ & $0.051 * * *$ \\
\hline & $(2.99)$ & $(3.01)$ \\
\hline \multirow[t]{2}{*}{ EARNVOL } & $-0.649 * * *$ & $-0.630 * * *$ \\
\hline & $(4.48)$ & $(4.35)$ \\
\hline \multirow[t]{2}{*}{$A G E$} & -0.000 & -0.000 \\
\hline & $(0.50)$ & $(0.46)$ \\
\hline \multirow[t]{2}{*}{$S I$} & 0.273 & 0.191 \\
\hline & $(0.68)$ & $(0.47)$ \\
\hline \multirow[t]{2}{*}{ NBSEG } & 0.002 & 0.002 \\
\hline & $(0.33)$ & $(0.47)$ \\
\hline \multirow[t]{2}{*}{$N G S E G$} & -0.001 & -0.000 \\
\hline & $(0.28)$ & $(0.08)$ \\
\hline \multirow[t]{2}{*}{$D L W$} & -0.108 & -0.103 \\
\hline & $(1.63)$ & $(1.55)$ \\
\hline \multirow[t]{2}{*}{ ANALYFOL } & $0.007 * * *$ & $0.007 * * *$ \\
\hline & $(4.14)$ & $(3.98)$ \\
\hline \multirow[t]{2}{*}{ HERFIN } & $0.133 * * *$ & $0.133 * * *$ \\
\hline & $(2.63)$ & $(2.63)$ \\
\hline \multirow[t]{2}{*}{ IROA } & $-0.263 *$ & $-0.279 *$ \\
\hline & $(1.75)$ & $(1.86)$ \\
\hline \multirow[t]{2}{*}{ Constant } & -0.059 & 0.117 \\
\hline & $(0.63)$ & $(0.90)$ \\
\hline Year FE & YES & YES \\
\hline Observations & 862 & 862 \\
\hline Adj. R-squared & 0.199 & 0.202 \\
\hline
\end{tabular}


TABLE 8

Additional Analyses (continued)

Panel B: The Impact of ESOP on Disclosure Score with the level of ESOP $\leq 5 \%$

ESOP

UNIONR

$E S O P \times U N I O N R$

SIZE

LIT

LEV

GROWTH

$R O A$

SEO

$M A$

EARNVOL

$A G E$

$S I$

NBSEG

NGSEG

$D L W$

ANALYFOL

HERFIN

IROA

Constant

Year FE

Observations

Adj. R-squared
(1)

DSCORE

0.046 ***

(2.99)

$-0.001$

(0.72)

(0.00)

$0.071 * * *$

(3.41)

$-0.035$

(1.64)

$-0.002$

$(0.25)$

$0.301 * * *$

(5.60)

0.039 *

(1.67)

$0.076^{* * * *}$

(6.81)

$-0.014$

(1.03)

0.000

(0.40)

-0.287 *

(1.86)

0.015 ***

(2.93)

$-0.005$

(1.14)

0.031

(0.38)

$0.007 * * *$

(6.39)

$0.155^{* * * *}$

(2.93)

0.017

(0.21)

0.029

(0.82)

YES

2,637

0.290
(2) DSCORE

0.007

(0.34)

$-0.002 * *$

(2.33)

$0.003 * * *$

(2.62)

0.002

(0.24)

$0.071 * * *$

(3.39)

$-0.036^{*}$

(1.67)

$-0.003$

(0.44)

$0.303 * * *$

(5.62)

0.039

(1.64)

$0.076^{* * *}$

(6.76)

$-0.012$

(0.90)

0.000

(0.30)

$-0.274 *$

(1.76)

$0.015 * * *$

(2.99)

$-0.006$

(1.18)

0.035

$(0.42)$

$0.007 * * *$

(5.99)

$0.157 * * *$

(2.99)

0.014

(0.17)

0.044

(1.23)

YES

2,637

0.295

T-statistics clustered by firm are presented in the parentheses. * significant at 10\%; ** significant at 5\%; *** significant at $1 \%$ (two-sided test). Variable definitions are provided in the Appendix. (Table 8 continued on next page) 
TABLE 8

Additional Analyses (continued)

Panel C: The Impact of ESOP on Disclosure Before and After Reg FD

\begin{tabular}{|c|c|c|}
\hline & $\begin{array}{l}\text { (1) } \\
\text { DSCORE, Before RegFD }\end{array}$ & $\begin{array}{l}\text { (2) } \\
\text { DSCORE, After RegFD }\end{array}$ \\
\hline \multirow[t]{2}{*}{ ESOP } & -0.010 & 0.009 \\
\hline & $(0.38)$ & $(0.35)$ \\
\hline \multirow[t]{2}{*}{ UNIONR } & $-0.002 * *$ & $-0.004 * * *$ \\
\hline & $(1.99)$ & $(3.29)$ \\
\hline \multirow[t]{2}{*}{$E S O P \times U N I O N R$} & 0.001 & $0.003 * *$ \\
\hline & $(0.74)$ & $(2.22)$ \\
\hline \multirow[t]{2}{*}{ SIZE } & -0.005 & 0.009 \\
\hline & $(0.86)$ & $(1.26)$ \\
\hline \multirow[t]{2}{*}{$L I T$} & 0.038 & $0.082 * * *$ \\
\hline & $(1.55)$ & $(3.20)$ \\
\hline \multirow{2}{*}{$L E V$} & 0.013 & -0.019 \\
\hline & $(0.54)$ & $(0.85)$ \\
\hline \multirow[t]{2}{*}{ GROWTH } & 0.009 & $-0.015^{*}$ \\
\hline & $(0.48)$ & $(1.66)$ \\
\hline \multirow[t]{2}{*}{$R O A$} & $0.295 * * *$ & $0.282 * * *$ \\
\hline & $(4.35)$ & $(3.55)$ \\
\hline \multirow[t]{2}{*}{ SEO } & -0.014 & $0.098 * * *$ \\
\hline & $(0.29)$ & $(2.92)$ \\
\hline \multirow[t]{2}{*}{$M A$} & $0.047 * * *$ & $0.059 * * *$ \\
\hline & $(2.74)$ & $(3.32)$ \\
\hline \multirow[t]{2}{*}{ EARNVOL } & -0.018 & $0.043 *$ \\
\hline & $(1.22)$ & $(1.77)$ \\
\hline \multirow[t]{2}{*}{$A G E$} & -0.000 & -0.001 \\
\hline & $(0.12)$ & $(1.54)$ \\
\hline \multirow[t]{2}{*}{$S I$} & $-0.525 * * *$ & -0.138 \\
\hline & $(2.60)$ & $(0.64)$ \\
\hline \multirow[t]{2}{*}{ NBSEG } & $0.014 * *$ & $0.018 * * *$ \\
\hline & $(2.17)$ & $(3.15)$ \\
\hline \multirow[t]{2}{*}{$N G S E G$} & 0.008 & -0.001 \\
\hline & $(1.04)$ & $(0.25)$ \\
\hline \multirow[t]{2}{*}{$D L W$} & -0.035 & $-0.130 * *$ \\
\hline & $(0.41)$ & $(2.17)$ \\
\hline \multirow[t]{2}{*}{ ANALYFOL } & $0.008 * * *$ & $0.010 * * *$ \\
\hline & $(5.63)$ & $(6.65)$ \\
\hline \multirow[t]{2}{*}{ HERFIN } & $0.132 * *$ & 0.014 \\
\hline & $(2.33)$ & $(0.22)$ \\
\hline \multirow[t]{2}{*}{ IROA } & 0.136 & $0.357 * *$ \\
\hline & $(1.08)$ & $(2.57)$ \\
\hline \multirow[t]{2}{*}{ Constant } & -0.037 & 0.041 \\
\hline & $(0.98)$ & $(0.97)$ \\
\hline Year FE & YES & YES \\
\hline Observations & 635 & 1,011 \\
\hline Adj. R-squared & 0.274 & 0.363 \\
\hline
\end{tabular}

